PNL-8662

UC-630

\title{
ARID SITE CHARACTERIZATION \\ AND TECHNOLOGY ASSESSMENT: \\ VOLATILE ORGANIC COMPOUNDS - \\ ARID INTEGRATED DEMONSTRATION
}

R. G. Riley

June 1993

Prepared for

the U.S. Department of Energy

under Contract DE-ACO6-76RLO 1830

Pacific Northwast Laboratory

Richland, Washington 99352 


\section{Summary}

Areas of common technology interests between the Volatile Organic Compounds-Arid Integrated Demonstration (VOC-Arid ID) and selected U.S. Department of Energy (DOE) arid and semiarid sites were identified based on identification, evaluation, and integration of the following information: 1) technologies currently being assessed in the VOC-Arid ID program, 2) data on subsurface contamination at DOE arid and semiarid sites, and 3) assessments of perceived technology needs to support waste site remediation activities at other DOE arid/semiarid sites.

Technologies under evaluation as part of DOE's VOC-Arid ID program fall into seven technical categories: 1) drilling and access technologies; 2) monitoring VOCs in situ and ex situ; 3) characterization (i.e., sampling and analysis) of chemical, geologic, and hydrologic properties; 4) enhanced extraction or containment of VOCs; 5) ex situ treatment of VOCs and co-contaminants; 6 ) in situ treatment (i.e., destruction) of VOCs and co-contaminants; and 7) data interpretation and design and evaluation of remediation systems. Specific technologies are identified in each category and the rationale for their need are described.

Subsurface contamination is described for 12 sites that were selected from a screening of 8 DOE arid/semiarid sites, using the chemistry of the subsurface of the Hanford Site's 200 West Area as a guideline. Sites selected contained known VOC contamination in the vadose zone and/or groundwater and, in many cases, also contained co-contaminants. The general nature of subsurface contamination ranged from complex mixtures in the vadose zone and/or groundwater to contamination confined to a limited area of the vadose zone and separated by hundreds of meters (hundreds to thousands of fiet) from the underlying uncontaminated aquifer.

Technology needs for the 12 selected sites were assessed based on information gathered through discussions with technical professionals familiar with environmental restoration activities at their sites and documents that address characterization and environmental restoration activities. This information was used in combination with VOC-Arid ID program technologies to identify areas of common interest between Hanfurd's VOC-Arid ID and other DOE arid/semiarid sites. Ex situ treatment and monitoring technologies appeared to be areas of greatest common interest; however, it is anticipated that interest in the broader spectrum of VOC-Arid ID technologies will increase as characterization data become more available and remediation strategies are identified and implemented at DOE sites.

Technology development, evaluation, and deployment at DOE sites is a dynamic process. Readers of this report, therefore, are encouraged to provide constructive 
comments on improving the accuracy and completeness of site characterization information and technology activities and how they were depicted in relation to VOC-Arid ID for sites described herein. All feedback will be given serious consideration for inclusion in future updates of this report. All comments should be addressed to VOC-Arid ID Coordinator, Steve Stein, at Pacific Northwest Laboratory, Seattle Research Center, 4000 N.E. 41 st Street, Seattle, WA 98105 or the VOC-Arid ID Pacific Northwest Laboratory Program Manager, Tom Brouns, at Pacific Northwest Laboratory, F.O. Box 999, MS K6-80, Richland, WA 99352. 


\section{Acknowledgments}

The Volatile Organic Compounds-Arid Integrated Demonstration (VOC-Arid ID) is supported by the U.S. Department of Energy's (DOE) Office of Technology Development.

Special thanks are extended to Tom Brouns and Stan Tomich for their input on VOCArid ID technologies and their understanding of environmental restoration technology needs at other DOE arid/semiarid sites.

The author also wishes to thank the many individuals at other DOE sites who provided site documents and personal insight necessary for the preparation of this report. Personal thanks go to Bev Johnston for the structural and editorial improvements that she made to the document. 


\section{Contents}

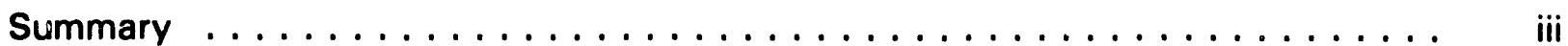

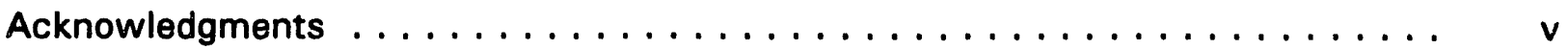

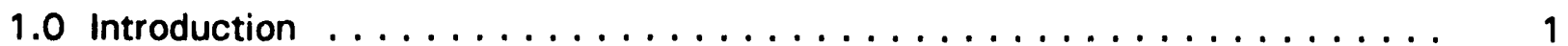

2.0 Arid Technology Evaluation $\ldots \ldots \ldots \ldots \ldots \ldots$

3.0 Subsurface Contaminant Assessment $\ldots \ldots \ldots \ldots \ldots$

4.0 Technology Considerations: Other DOE Sites . . . . . . . . . . . . 11

Idaho National Engineering Laboratory . . . . . . . . . . . . . . . . . . 11

Radioactive Waste Management Complex . . . . . . . . . . . . . . 11

Test Area North . . . . . . . . . . . . . . . . . . . . . . . . . 11

Lawrence Livermore National Laboratory . . . . . . . . . . . . . . . 12

Main Site . . . . . . . . . . . . . . . . . . . . . . . 12

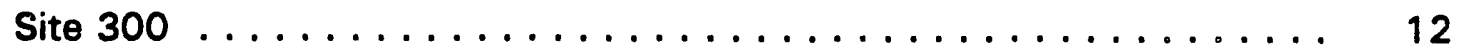

Los Alamos National Laboratory . . . . . . . . . . . . . . . . . 13

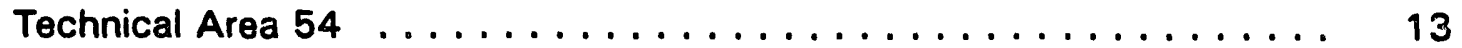

Nevada Test Site .......................... 13

Pantex Plant . . . . . . . . . . . . . . . . . . . . 13

Rocky Flats Plant $\ldots \ldots \ldots \ldots \ldots \ldots \ldots \ldots \ldots \ldots \ldots \ldots \ldots$

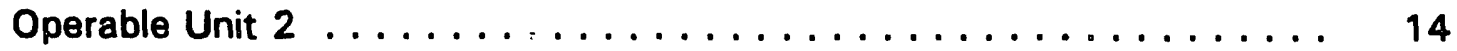

Operable Unit $4 \ldots \ldots \ldots \ldots \ldots \ldots \ldots \ldots \ldots \ldots \ldots$

Sandia National Laboratories . . . . . . . . . . . . . . . . . . . . . . 14

Chemical Waste and Mixed Waste Landfills . . . . . . . . . . . . . . . 14

5.0 Areas of Potential Common Technology Interests $\ldots \ldots \ldots \ldots$

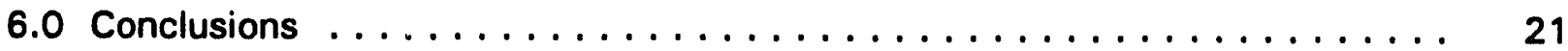

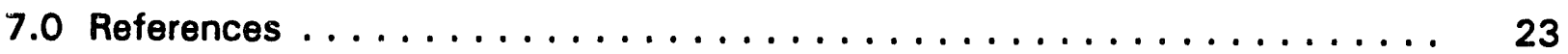

Appendix A - Site Subsurface Characterization Summaries . . . . . . . . . . A.1

Appendix B - Bibliography ........................ B.1 


\section{Figure}

1 Location and Size of Selected Arid/Semiarid Sites $\ldots \ldots \ldots \ldots \ldots$

\section{Tables}

1 Technology Evaluation: Volatile Organic Compounds -

Arid Integrated Demonstration

2 Subsurface Contamination at Selected Aird/Semiarid Sites . . . . . . . . . . 9

3 Areas of Potential Common Technology Interest at U.S. Department of Energy Arid/Semiarid Sites 


\subsection{Introduction}

The U.S. Department of Energy's (DOE's) Volatile Organic Compounds-Arid Integrated Demonstration (VOC-Arid ID) program was initiated in March 1991 to evaluate technologies for all phases of remediation of VOCs in soils and groundwater at DOE arid/semiarid sites. The primary site for field demonstrations under the VOC-Arid ID program is the Hanford Site.

The purpose of this report is to describe 1) the bases for technologies currently under evaluation in the VOC-Arid ID program; 2) the types of subsurface contamination at DOE arid/semiarid sites; and 3) the areas of potential common technology interests based on perceived technology needs at other DOE sites.

This report was compiled by Pacific Northwest Laboratory(a) in response to DOE's Office of Technology Development's mission to carry out an aggressive program to accelerate the development and implementation of new and existing technologies to meet a 30-year goal set by DOE in June 1989 to clean up all of its sites and to bring all sites into compliance with current and future environmental regulations. A key component of this program is the development of technologies that are better, faster, safer, and cheaper than those technologies currently available.

Included in this report are an evaluation of technologies currently (fiscal year 1993) being pursued at the Hanford Site under the auspices of the VOC-Arid ID program (Section 2.01, an assessment of subsurface contaminants at arid/semiarid sites (Section 3.0), a summarization of technologies under consideration at other DOE sites (Section 4.0), a discussion of areas of potential common technology interests (Section 5.0), and the conclusions (Section 6.0). Also included are Section 7.0 (references cited in the text of the report): Appendix A, a summary of the extent of contamination at the DOE arid/semiarid sites under consideration; and Appendix B, a bibliography of source documents from which this report was prepared.

(a) Pacific Northwest Laboratory is operated for the U.S. Department of Energy by Battelle Memorial Institute. 


\subsection{Arid Technology Evaluation}

The bases for the technologies currently being evaluated in the VOC-Arid ID program are summarized in Table 1. The technical areas, needs, and proposed technology solutions described are dynamic and subject to modification. The modifications would be based on the relative success of technology development and demonstration at the Hanford Site and augmented with the guidance/support that the program can obtain from other technical assessments (e.g., Chem-Nuclear Geotech, Inc. 1991; Junk 1992), experiences, needs, capabilities, information exchange, and collaboration with other DOE sites, universities, and the private sector. University participation is promoted through the subcontract process, and capabilities in the commercial sector are solicited through procurements or establishment of Cooperative Research and Development Agreements.

Technology development and demonstration by the VOC-Arid ID program are currently being driven by two factors:

- the need to provide the next generation of technology supporting the DOE's ongoing Environmental Restoration Program, such as the Expedited Response Action in the Hanford Site's 200 West Area; there, current technology is focused on the vacuum extraction of large quantities (hundreds of metric tons) of carbon tetrachloride $\left(\mathrm{CCl}_{4}\right)$ from the vadose zone underlying three cribs

- the need to develop and demonstrate technologies that can be deployed to address subsurface VOC contamination at all DOE's arid sites (and measure remediation effectiveness) especially where remediation may be significantly impacted by the presence of co-contaminants (e.g., heavy metals, radionuclides, significant quantities of other semivolatile and nonvolatile organics).

Example near-term technology needs include 1) sensors for real-time monitoring of VOCs in vacuum-pumped gas streams, vadose zone, and groundwater and 2) costeffective ex situ treatment of VOCs and associated co-contaminants in gas and liquid streams. In parallel, there is a need for more efficient and effective deployment and application of advanced tools for characterization of the vadose zone and groundwater underlying the site. Associated with some of these tools are devices that will allow their effective deployment in the subsurface. Information from demonstration of such tools will provide 1) insight on VOC depletion from the vadose zone; 2) data for planning the demonstration of the remediation of residual VOCs and associated co-contaminants, based on developing in situ and ex situ treatment technologies; and 3) development of complex data integration/interpretation capabilities and predictive tools to enhance statistical evaluation and assessment and to design, monitor, and control technology deployment. Applied in situ technologies emphasize biodegradation, chemical destruction, enhanced removal, or techniques to remove (bulk or residual VOCs) or contain VOCs in the ground. In the case 
of in situ technologies, better access to the vadose zone and/or groundwater is needed to increase the potential for success of in situ treatment. This issue is being addressed through the testing of directional drilling and penetration techniques and use of novel multiscreened wells to enhance both physical and biological treatment. 


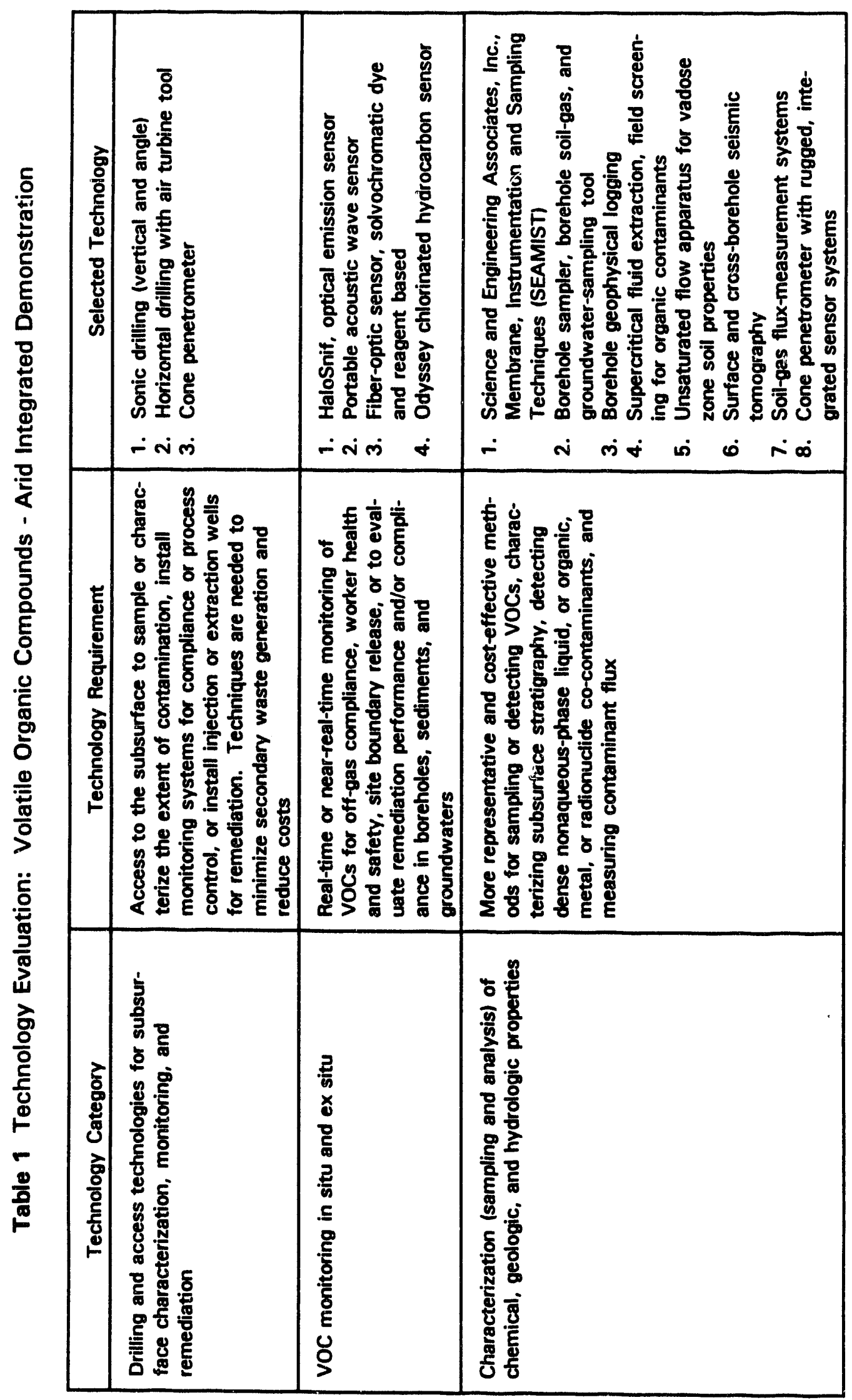




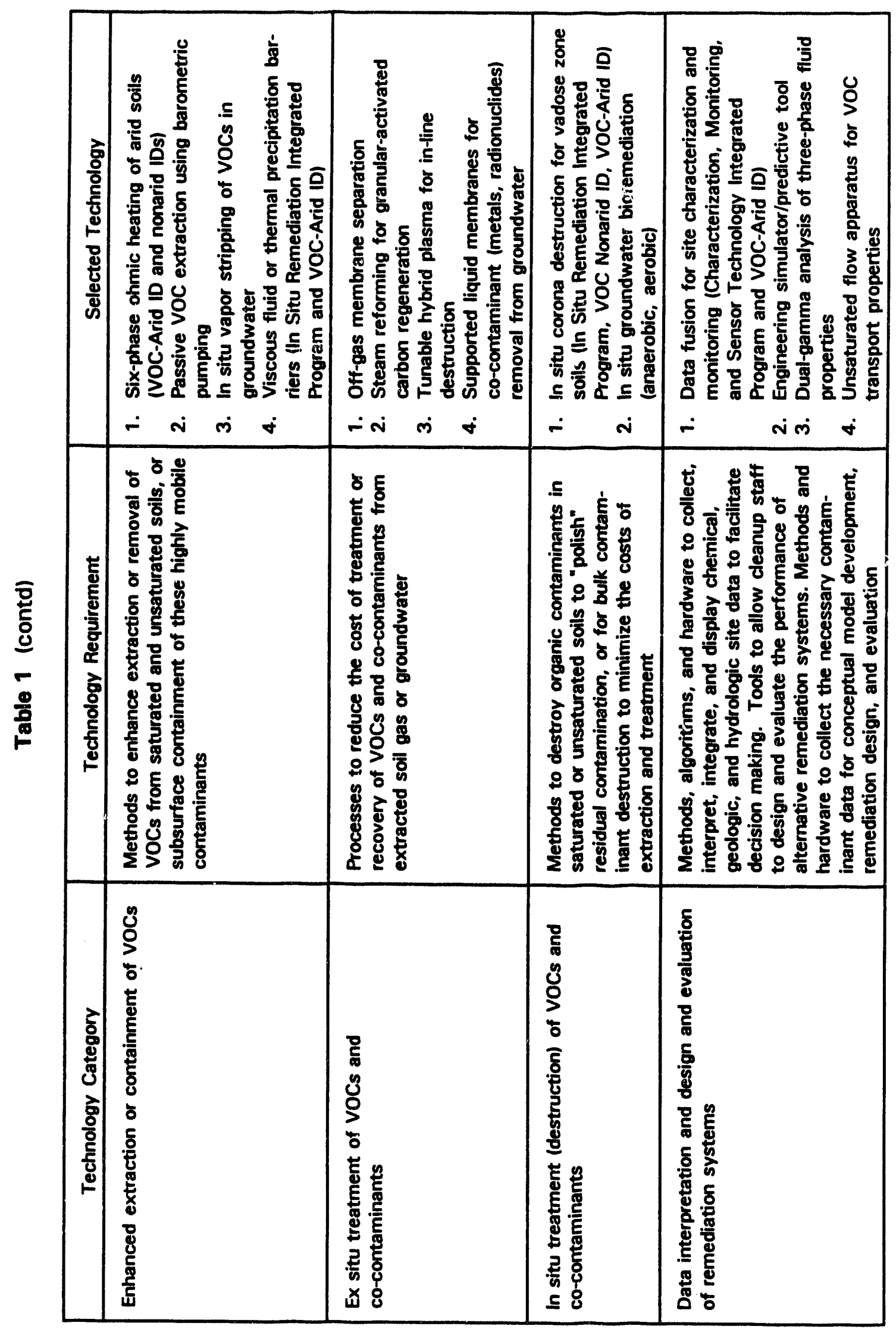




\subsection{Subsurface Contaminant Assessment}

Because the primary focus of the program is the VOCs in the vadose zone and/or groundwater of arid/semiarid sites, with an emphasis on $\mathrm{CCl}_{4}$ and associated co-contaminants (e.g., metals, anions, radionuclides, and other organics), sites at eight DOE installations with similar subsurface environments (Hanford Site, Idaho National Engineering Laboratory, Lawrence Livermore National Laboratory, Los Alamos National Laboratory, Nevada Test Site, Pantex Plant, Rocky Flats Plant, and Sandia National Laboratories; Figure 1) were selected, based on a history of subsurface VOC contamination, for assessment.

The general nature of the subsurface contamination at the selected sites is summarized in Table 2. The contamination ranges from complex mixtures in the vadose zone and/or groundwater (e.g., surface disposal of wastes or injection of wastes into deep wells) to contamination confined to a limited area of the vadose zone and separated by hundreds of meters (hundreds to thousands of feet) from the underlying uncontaminated aquifer. More specific descriptions of the nature of subsurface contamination at selected sites can be found in Appendix A. References used to obtain the information provided in Appendix A are listed in Appendix B. Some general observations follow.

Significant concentrations (100 to $10,000 \mu \mathrm{g} / \mathrm{L}$ ) of $\mathrm{CCl}_{4}$ have been measured in groundwater (or perched water) at three sites: Hanford's 200 West Area, Idaho's Radioactive Waste Management Complex, and Rocky Flats' East Trenches/903 Pad Operable Unit 2. Like Hanford, the Idaho and Rocky Flats sites have a history of near-surface codisposal of VOCs with significant quantities of ma , anions, radionuclides, and other organics. The injection well at Idaho's Test Area North has been used to release VOCs, metals, and radionuclides to the underlying Snake River Plain aquifer, while the surrounding vadose zone has remairied virtually unimpacted.

The chemistry of contamination at Livermore's Main Site differs from the more complex sites, in that it consists mainly of VOCs, though there are isolated areas of fuel hydrocarbon, tritium, and metals contamination. Contamination exists in both the vadose zone and groundwater at the Livermore site.

The main VOC contamination at Livermore's 834 Complex is trichloroethylene (TCE), commingled with other oily organics. The organic mixture is contaminating the vadose zone and a zone of perched water but not the underlying confined aquifer. Similarly, Pantex's Zone 12 contains a highly contaminated vadose zone (solvents, metals, pesticides, polychlorinated biphenyls, fuel hydrocarbons, high explosives, uranium, etc.) and an underlying zone of perched water is contaminated with measurable quantities of chlorinated hydrocarbons, metals, and high explosives. 


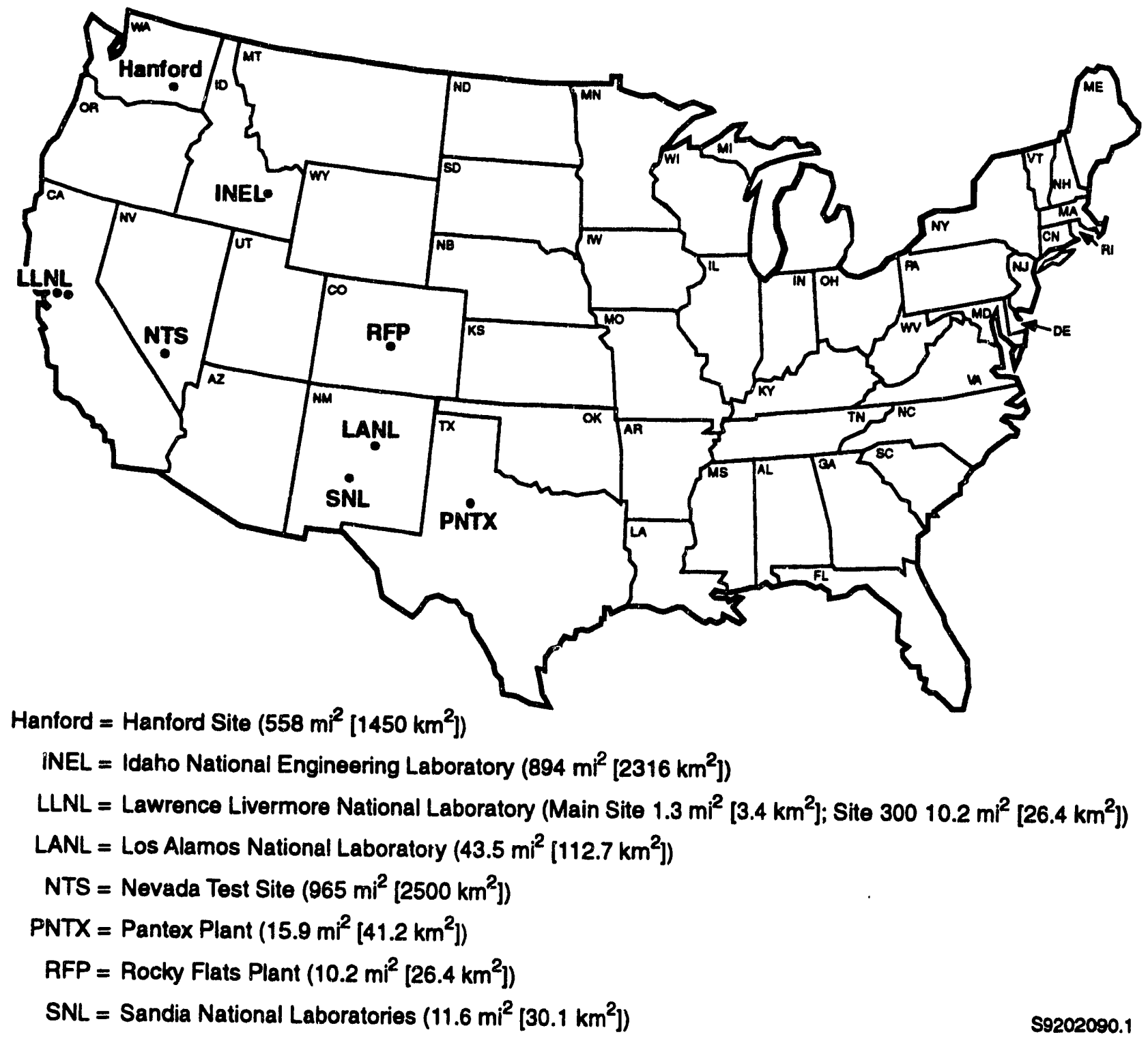

Figure 1 Location and Size of Selected Arid/Semiarid Sites

The Los Alamos and Sandia waste sites contain VOCs codisposed with other chemical contaminants. At these sites, contamination appears to be limited to the vadose zone, though trace concentrations of TCE have been detected recently in the underlying groundwater aquifer at Sandia's Chemical Waste Landfill. Areas of perched water have not been detected at these sites. 
Table 2 Subsurface Contamination at Selected Arid/Semiarid Sites

\begin{tabular}{|c|c|c|c|c|c|}
\hline Location & $\begin{array}{c}\text { Volatile } \\
\text { Organic } \\
\text { Compounds }\end{array}$ & Metals & Anions & Radionuclides & $\begin{array}{c}\text { Other } \\
\text { Organics }\end{array}$ \\
\hline \multicolumn{6}{|c|}{ Hanford Site } \\
\hline 200 West Area & $\mathrm{G}, \mathrm{S}\left(\mathrm{CCl}_{4}\right)$ & $\mathbf{P}(\mathbf{G}, \mathbf{S})$ & $\mathbf{P}(\mathbf{G}, \mathbf{S})$ & $\mathbf{P}(\mathbf{G}, \mathbf{S})$ & $\mathbf{P}(\mathbf{S})$ \\
\hline \multicolumn{6}{|c|}{ Idaho National Engineering Laboratory } \\
\hline $\begin{array}{l}\text { Radioactive Waste } \\
\text { Management Complex } \\
\text { Test Area North }\end{array}$ & $\begin{array}{l}\mathrm{G}, \mathbf{S}\left(\mathrm{CCl}_{4}\right) \\
\mathrm{G}, \mathbf{S}\end{array}$ & $\mathbf{P}(\mathbf{G})$ & $\mathbf{P}(\mathbf{S})$ & $\begin{array}{l}P(S) \\
P(G)\end{array}$ & $\mathbf{P}(\mathbf{S})$ \\
\hline \multicolumn{6}{|c|}{ Lawrence Livermore National Laboratory } \\
\hline $\begin{array}{l}\text { Main Site } \\
\text { Site } 300\end{array}$ & $\begin{array}{l}\text { G,S } \\
\text { G,S }\end{array}$ & $\mathbf{P}(\mathbf{G})$ & & $\mathbf{P}(\mathbf{G}, \mathbf{S})$ & $\begin{array}{l}P(G, S) \\
P(G, S)\end{array}$ \\
\hline \multicolumn{6}{|c|}{ Los Alamos National Laboratory } \\
\hline Test Area 54 & $\mathbf{S}$ & $\mathbf{P}(\mathbf{S})$ & & & $\mathbf{P}(\mathbf{S})$ \\
\hline \multicolumn{6}{|c|}{ Nevada Test Site (no data) } \\
\hline \multicolumn{6}{|c|}{ Pantex Plant } \\
\hline Zone 12 & $\mathbf{G}, \mathbf{S}$ & $\mathbf{P}(\mathbf{G}, \mathbf{S})$ & & $\mathbf{P}(\mathbf{S})$ & $\mathbf{P}(\mathbf{G}, \mathbf{S})$ \\
\hline \multicolumn{6}{|c|}{ Rocky Flats Plant } \\
\hline Operable Unit 1 & $\mathbf{G}, \mathbf{S}$ & $\mathbf{P}(\mathbf{G}, \mathbf{S})$ & $\mathbf{P}(\mathbf{G})$ & $\mathbf{P}(\mathbf{G}, \mathbf{S})$ & \\
\hline Operable Unit 2 & $\mathbf{G}\left(\mathrm{CCl}_{4}\right), \mathbf{S}$ & $\mathbf{P}(\mathbf{G})$ & $\mathbf{P}(\mathbf{G})$ & $\mathbf{P}(\mathbf{G})$ & \\
\hline Operable Unit 4 & G,S & $\mathbf{P}(\mathbf{S})$ & $\mathbf{P}(\mathbf{G}, \mathbf{S})$ & $\mathbf{P}(\mathbf{G}, \mathbf{S})$ & \\
\hline \multicolumn{6}{|c|}{ Sandia National Laboratories } \\
\hline $\begin{array}{l}\text { Chemical Waste } \\
\text { Landfill }\end{array}$ & $\mathbf{G}, \mathbf{S}$ & $P(S)$ & $P(S)$ & & $P(S)$ \\
\hline $\begin{array}{l}\mathbf{G}=\text { Measured in grour } \\
\mathbf{S}=\text { Measured in soil/s } \\
\mathbf{P}=\text { Present based on }\end{array}$ & $\begin{array}{l}\text { vater. } \\
\text { ment or soil } \\
\text { orical record }\end{array}$ & s. & ent date & & \\
\hline
\end{tabular}




\subsection{Technology Considerations: Other DOE Sites}

This section summarizes technology needs at DOE arid and semiarid sites other than Hanford. Information resources for this section included 1) discussions with technical professionals familiar with environmental restoration activities at the sites discussed in Section 3.0 and 2) review of the technical information documents referenced in Appendix B.

\section{Idaho National Engineering Laboratory}

\section{Radioactive Wast $\sim$ Management Complex}

Vacuum extraction of VOCs from the vadose zone is being considered as a possible option, with subsequent ex situ treatment (catalytic destruction of VOC vapors). Enhanced modeling capabilities are needed to predict vadose zone transport of VOCs in a complex subsurface environment, consisting of fractured basaltic lava flows with layers of sedimentary interbeds. From this perspective, interest has also been expressed in the capabilities of the unsaturated flow apparatus (UFA ${ }^{\mathrm{m}}$; Beckman Instruments, Inc., Palo Alto, California). Reliable sampling and analytical tools (e.g., renewable vapor-phase sensor) are needed to measure vapor-phase VOCs and solid/liquid VOCs in fractured basalts. Along these lines, interest has been expressed in the cone penetrometer and its linkage to rugged integrated sensor systems.

As the designated site for the conduct of the Buried Waste Integrated Demonstration (BWID) program, other areas of technology needs include 1 ) intrusive (e.g., locating critical radiological and chemical risk assessment source terms) and nonintrusive site characterization; 2) nondestructive assay; 3) waste retrieval, followed by ex situ treatment; 4) ex situ treatment (pretreatment, primary and secondary [e.g., off-gas-treatment technology]) and in situ treatment, followed by long-term monitoring or retrieval; 5) retrieval, followed by in situ stabilization or retrieval; 6) contaminant/waste containment and stabilization; and 7) waste disposal/storage.

\section{Test Area North}

Remediation strategies for the Test Area North/Technical Support Facility injection well are currently focused on removal (bailing of sludges and solids and removing a potentially present VOC liquid layer) of contaminants and contaminated materials from source term and treatment of groundwater. There does not appear to be a need for vadose zone characterization/treatment because of the history of the nature of disposal. A Resource Conservation and Recovery Act of 1976 (RCRA)-permitted water-treatment facility is to be used at the injection well to pump and treat (carbon adsorption of VOCs, ion exchange 
of metals and radionuclides) the groundwater. More cost-effective methods for ex situ treatment of contaminated groundwater are of interest. Consideration is being given to testing a German in situ air-stripping technology for removing VOCs from peripheral wells. In situ bioremediation is a possible option for consideration at this site.

\section{Lawrence Livermore National Laboratory}

\section{Main Site}

At Livermore's Main Site, a "smart" remediation strategy is being implemented that involves pumping and treatment of groundwater, subsurface characterization (lithology and contaminant distribution), and modeling. Subsurface characterization information and modeling are used to direct pump-and-treat activities (e.g., rate and duration of pumping, selection of wells to pump), including the evaluation of pump-and-treat performance and the close monitoring of VOC distribution to prevent movement into less permeable zones (making matters worse). Subsurface data (e.g., distribution coefficients, retardation factors, and lithology) and advances in model development are needed to improve 1) predictive models where data obtained from additional well placement may be limited and 2) pump-and-treat strategy design and performance.

Vacuum-induced venting is currently being evaluated for application at selected vadose zone source terrns of VOC at the Main Site. Deployment of the "smart" remediation strategy currently suggests a 30-year time frame for restoration of the groundwater. Improvements in the overall strategy are anticipated to reduce restoration time.

\section{Site 300}

\section{Complex}

Soil-vapor extraction is currently being evaluated for the removal of VOCs (i.e., TCE) from the vadose zone in low-permeability sediments. Generation of high vacuum in the vadose zone has led to mounding of the shallow water table, resulting in the need to simultaneously remove water to the surface for treatment. The presence of oily co-contaminants in the extracted water led to emulsions that made simple aeration for the removal of TCE difficult. Manifolding to a greater number of wells, coupled with lower vacuum, has allowed for the separation of vapor extraction and liquid pumping. Future treatment of the liquid includes skimming of the oily material prior to aeration. Vapor-phase air-treatment activities include 1) in situ regeneration of adsorbant carbon by steam distillation/co-condensation of TCE and steam with TCE recovery from a phase separator, 2) pulsed high-energy ultraviolet light to photolyze the TCE in the vapor phase, and 3) pilot-scale pyrolysis. Vapor-stream monitoring will be by computer-controlled, 
low-cost, dual-detector gas chromatography. In situ microbial filters in the shallow groundwater upgradient of the vacuum-induced venting system are being considered as a polishing technology.

\section{Landfill Pit 6}

Because the primary source of VOCs in groundwater is Landfill Pit 6 and because of the potential for offsite migration, remedial options under consideration include soil-vapor and groundwater extraction, with treatment of removed chemical by such approaches as volatilization to the atmosphere, thermal oxidation, ultraviolet $/ \mathrm{H}_{2} \mathrm{O}_{2}$, carbon adsorption and recovery, and land farming/biodegradation.

\section{Los Alamos National Laboratory}

\section{Technical Area 54}

Los Alamos is currently taking voluntary corrective action at this site because of its desire to contain the VOC plume such that expansion of the adjacent radioactive waste site toward the chemical waste site can be done without potentially creating an area of mixed waste. Interest is focused on characterization of the surge beds. Along this line, interest has been expressed in 1) the drilling of a new borehole for testing of the SEAMIST device to obtain information on the vertical extent of VOC contamination and 2) the permanent finish of the port with the SEAMIST bed for continuous monitoring. There is also interest in some form of in situ barrier technology (e.g., active biobarrier) that could be placed at the intersection of the surge beds and boreholes to eliminate the vertical transport of VOCs via open boreholes. Technology to cost effectively determine contaminant distribution coefficients in unsaturated rock and other porous media would be valuable in understanding contaminant sorption behavior as a function of the remediation strategy applied.

\section{Nevada Test Site}

The technology needed at this site is unknown at this time.

\section{Pantex Plant}

Site characterization activities are in the early stages of development and are being carried out under a RCRA permit. These activities have consisted of soil-gas surveys and analyses of perched water and sediment samples from well-drilling activities. Evaluation of results to date indicate a subsurface that consists of tight clay and caliche layers. 
Characterization work to date has not identified any significant groundwater (perched water) plumes. Because of the highly impermeable nature of the subsurface underlying Pantex, the focus is on the conduct of sufficient cost-effective subsurface characterization to identify the best remediation strategies. Interest has been expressed in fieldtransportable analytical technologies, including real-time measurement devices to further characterize the site and reduce characterization costs.

\section{Rocky Flats Plant}

\section{Operable Unit 2}

Vacuum extraction of VOCs in the vadose zone is being considered a possible option for treating the VOC source term. Horizontal characterization of subsurface contamination is reasonably defined; however, the vertical distribution of contamination is not welldefined. Real-time sensor capability for measuring VOCs (and other contaminants, such as uranium) in vadose zone and ground water would be valuable. In situ bioremediation is considered a promising technology for application at this site.

\section{Operable Unit 4}

There is extreme interest in the potential application of directional drilling techniques at this site. In addition, interest has been expressed in the VOC-Arid ID engineering simulator as a technique to evaluate bioremediation of nitrates.

\section{Sandia National Laboratories}

\section{Chemical Waste and Mixed Waste Landfills}

Areas of characterization technology needs include 1) in situ sensors and sampling devices (must include radionuclides) that are deployable with directionally drilled boreholes and membrane borehole liners, 2) sampling strategy and optimization for risk estimation (with application to directionally drilled holes), 3) nonintrusive characterization methods (for delineation of pit boundaries and estimating waste type and volumes), 4) fieldscreening characterization technologies (for metals, VOCs, and low-level radioactivity), 5) vadose zone postclosure monitoring (for metals, VOCs, and radionuclides), and 6) subsurface access and sampling. Sandia has an interest in future development of the cone penetrometer capabilities. 
Areas of remediation technology needs include 1) in situ extraction (e.g., active and passive soil ventilation, soil washing, eletrokinetics), 2) transformation (e.g., reduce toxicity and mobility of contaminants), 3) containment (aboveground and belowground), and 4) stabilization (e.g., creating in situ waste forms by binding of waste to stabilization agents). 


\subsection{Areas of Potential Common Technology Interests}

In this section, areas of potential common technology interests between the VOC-Arid ID program and other DOE installations are briefly described. Resources used for this assessment include Sections 2.0 and 4.0 and information gained from discussions with technical professionals familiar with environmental restoration strategies under implementation or consideration at specific sites. Table 3 summarizes the areas of potential common technology interest, based on integration of the different information resources. In integrating the information, the author, in some cases, took the liberty to infer possible interest in Hanford technology at other sites. For example, Livermore indicated application of soil-vapor extraction to selected vadose source terms. In application of this technology, they might be interested in ex situ VOC-monitoring tools under evaluation at Hanford. A blank in the table for selected technologies at specific sites does not imply lack of potential applicability of the technology at a site; rather, the table reflects information available to the author at the time of its preparation.

There appears to be a significant potential common interest in the areas of ex situ VOC destruction, separation, and monitoring technology. Several of the sites (Idaho, Livermore, Rocky Flats) are using or have plans to use vacuum-extraction technology for the removal of VOCs from the vadose zone. Ex situ treatment of VOC off-gas streams is currently being done with conventional technologies (e.g., carbon adsorption, aeration), with technology development at other sites focused on systems such as membrane separation and catalytic destruction.

There is a possible opportunity for collaboration on the application of fiber-optic sensors to off-gas streams containing $\mathrm{CCl}_{4}$ between the VOC-Arid ID and Idaho's Radioactive Waste Management Complex or Rocky Flats' Operable Unit 2.

Common interest has also been expressed in the areas of characterization and monitoring technologies. For example, a few sites have expressed interest in advanced borehole completion techniques for testing of devices (such as SEAMIST), while others have expressed specific interest in in-situ sensors for measurement of VOCs (Rocky Flats) and metals and anions (Rocky Flats and Sandia). In the latter case, technology transfer is under way through Sandia's Mixed Waste Landfill ID for onsite analysis of metals in soils/sediments. The focus of Pantex is on the conduct of sufficient cost-effective subsurface characterization to justify the best possible remediation strategies; thus, the interest is in vadose-zone- and groundwater-monitoring tools. Possible opportunities for testing field-screening technologies for the measurement of organic co-contaminants include Idaho's Radioactive Waste Management Complex, Livermore's Site 300, and Rocky Flats' Operable Units 1 and 2. 


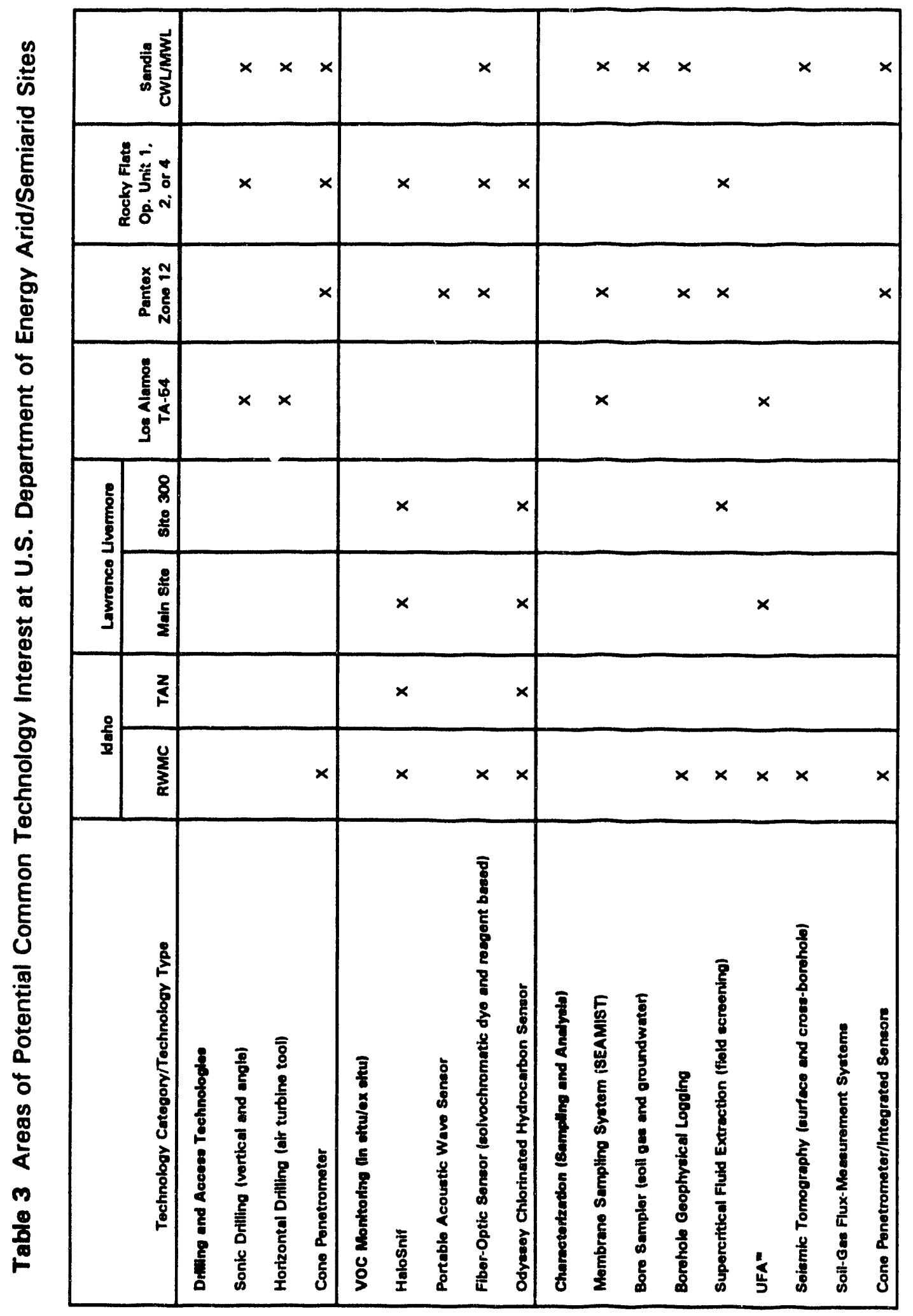




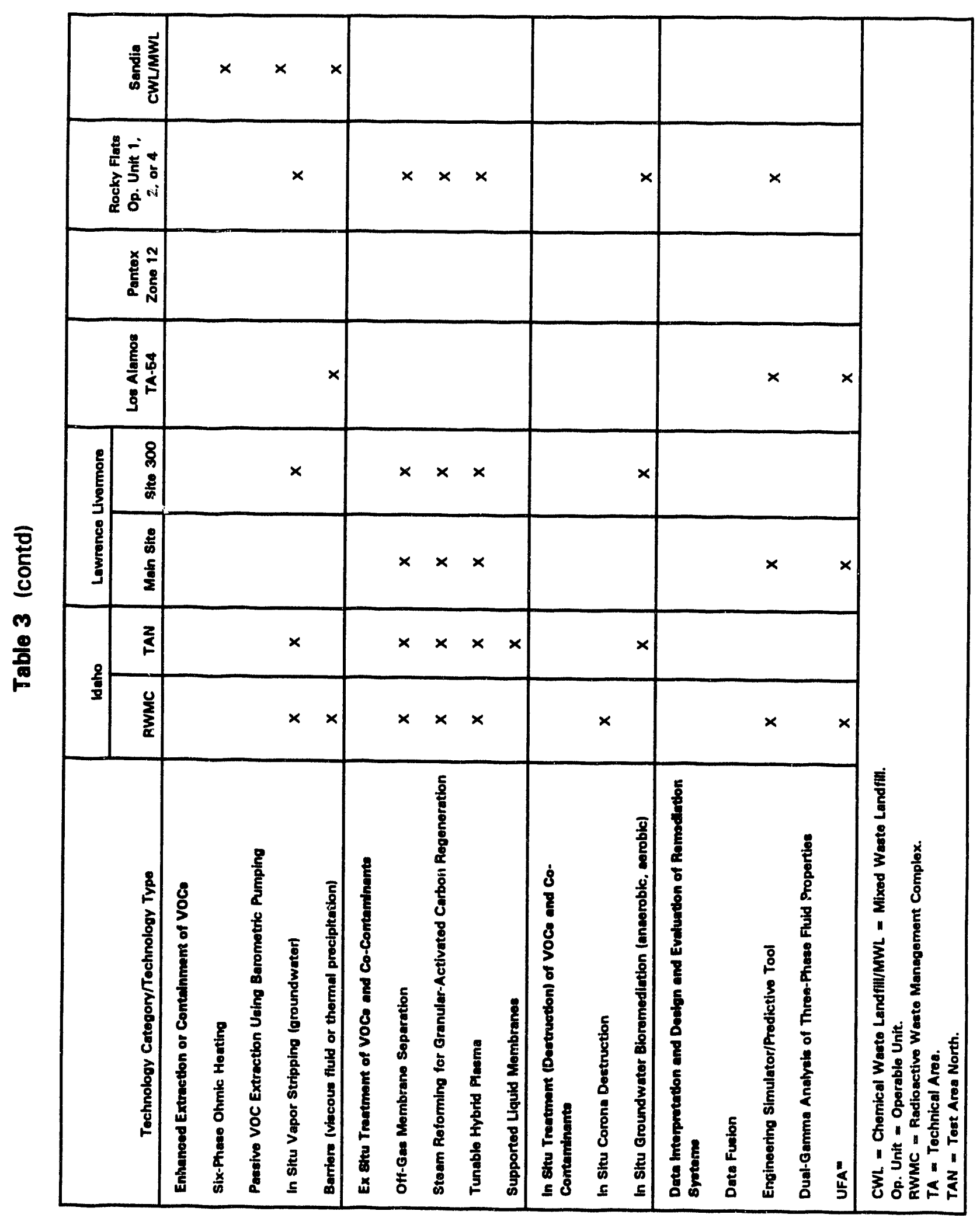


Interest has been expressed in developments in drilling and access tachnology. Rocky Flats is very interested in potential application of directional drilling tec' 'niques to their Operable Unit 4. Sandia and Idaho have expressed interest in application of the cone penetrometer to their site problems.

Of the sites expressing interest in in-situ microbiological destruction of VOCs, Rocky Flats' Operable Unit 2 appears to have the greatest commonality (and greatest opportunity for initial collaboration) with Hanford because of the presence of significant quantities of $\mathrm{CCl}_{4}$. Other sites focused on possible application of in situ microbiological destruction of TCE in groundwater (e.g., Idaho's Test Area North and Livermore's Site 300) may be able to take advantage of knowledge gained from ongoing studies of bioremediation of $\mathrm{CCl}_{4}$ in Hanford groundwater and bioremediation of TCE at the VOC-Nonarid ID (Savannah River).

Three sites (Idaho's Radioactive Waste Management Complex, Livermore's Main Site, and Los Alamos' Technical Area 54) expressed strong interest in obtaining cost-effective and reliable subsurface physicochemical and hydrologic data (e.g., diffusion coefficients, hydraulic conductivity, distribution coefficients, and retardation factors). These data will support characterization of their sites and will assist development and application of predictive tools to enhance performance assessment capabilities and to design, monitor, and control remediation technology deployment. There appears to be strong opportunity for future technology transfer of VOC-Arid ID UFA ${ }^{m}$ and remediation engineering simulator technologies to other DOE arid/semiarid sites. In the case of the engineering simulator technology, Rocky Flats has expressed interest in its potential application to bioremediation of nitrates in groundwater at Operable Unit 4. 


\subsection{Conclusions}

The VOC-Arid ID program is evaluating a number of technologies that, through technology transfer, would improve the cost effectiveness of environmental restoration activities at DOE sites. Advanced technologies under investigation involve the areas of 1) drilling to ottain subsurface access; 2) VOC monitoring (in situ and ex situ); 3) characterization for sampling and analysis of chemical, geologic, and hydrogeologic properties; 4) enhanced extraction or containment of VOCs; 5) ex situ treatment of VOCs and cocontaminants; 6) in situ treatment (destruction) of VOCs and co-containments; and 7) data interpretation and design and evaluation of remediation systems.

Subsurface chemistry at Hanford's 200 West Area was compared to other DOE arid/semiarid sites that are contaminated by VOCs. Idaho's Radioactive Waste Management Complex and Rocky Flats' Operable Unit 2 indicated a history of subsurface disposal of $\mathrm{CCl}_{4}$ and other co-contaminants comparable in complexity to Hanford. The nature of subsurface contamination at other sites appeared less complex (e.g., Livermore's Main Site), though this perception is likely to change at some sites (e.g., Pantex) as additional characterization data become available.

Information on technology under evaluation in the VOC-Arid ID program at Hanford was compared to technology needs at the other DOE arid/semiarid sites as a basis for identifying areas of potential common technology interests. Areas of potential common interest appear to be many, with opportunities for increased interest as additional data from contaminant characterization of DOE waste sites become available and remediation strategies are identified and implemented. 


\subsection{References}

Chem-Nuclear Geotech, Inc. 1991. Technology Needs and Assessment Final Report. DOE/ID/1 2584-92, Vols. 1 and 2, GJPO-104, U.S. Department of Energy, Idaho Field Office, Grand Junction, Colorado.

Junk, G. A. 1992. Characterization-Monitoring Technology Projects for Volatile Organic Compounds (VOCs), VOC Vadose Zone/Groundwater Characterization Technologies, TTP CH-1211-01, Arid-VOC ID, Subtask 3. Prioritization of Technology Projects. Ames Laboratory, Institute for Physical Research and Technology, lowa State University, Ames, lowa. 


\section{Appendix A}

\section{Site Subsurface Characterization Summaries}




\section{Appendix A}

\section{Site Subsurface Characterization Summaries}

\section{Hanford Site}

Aqueous and organic wastes containing carbon tetrachloride $\left(\mathrm{CCl}_{4}\right)$ from plutoniumrecovery processes at the Hanford Site's Plutonium Finishing Plant (200 West Area) were discharged primarily to three liquid waste disposal facilities: the 216-Z-1A tile field, the 216-Z-9 trench, and the 216-Z-18 crib. An estimated 363,000 to $580,000 \mathrm{~L}^{(1)}(96,000$ to $153,000 \mathrm{gal}^{(\mathrm{a})}$ of $\mathrm{CCl}_{4}$ were disposed to the subsurface in the 200 West Area. Cocontaminants and/or degradation products include chloroform; mono-, di-, and tributyl phosphate:s; dibutyl butyl phosphonate; laro oil (a complex mixture of triglycerides); cadnnium; nitrates; hydroxides; fluorides; sulfates; and various radionuclides, primarily plutonium and americium.

The $\mathrm{CCl}_{4}$ plume (Figure A.1) covers at least $5 \mathrm{~km}^{2}\left(1.9 \mathrm{mi}^{2}\right)$, virtually all of Hanford's 200 West Area north and east of the $\mathrm{CCl}_{4}$ discharge area. The highest concentration measured ir. the upper part of the aquifer $(8700 \mu \mathrm{g} / \mathrm{L})$ was found approximately $450 \mathrm{~m}$ ( $1476 \mathrm{ft}$ ) downgradient from the liquid disposal facilities. Concentrations of $\mathrm{CCl}_{4}$, as high as $72.7 \mu \mathrm{g} / \mathrm{mL}$ (soil gas), were detected in underlying soils at a depth of $1.2 \mathrm{~m}(4 \mathrm{ft}$ ) (Figure A.2). Chloroform, trichloroethylene (TCE), and tetrachloroethylene were also detected in the soil gas at maximum concentrations of 10 to 100 times lower than $\mathrm{CCl}_{4}$ (e.g., see chloroform plume map in Figure A.3). Other contaminants that partially intersect the grolindwacer plume include cyanide, fluoride, hexavalent chromium, TCE, nitrate, tritium, ${ }^{20} \mathrm{Tc},{ }^{129} \mathrm{I}$, and uranium.

\section{Idaho Nấional Engineering Laboratory}

\section{Radioactive Waste Menagement Complex}

At Idaho's Radioactive Waste Management Complex, several volatile organic compouivi ('VOC) plumes (Figure A.4) have been identified in the vadose zone underlying the Solid Waste Disposal Area as a result of the release, prior to 1970 , of $334,620 \mathrm{~L}$ $(88,400 \mathrm{gal})$ of organic waste. This organic waste consisted of $90,847 \mathrm{~L}(24,000 \mathrm{gal})$ of

(a) The referenced material, from which units cited in this report were taken, often used only English or only metric; therefore, for ease of cross referencing, this report gives both units of msasure. 


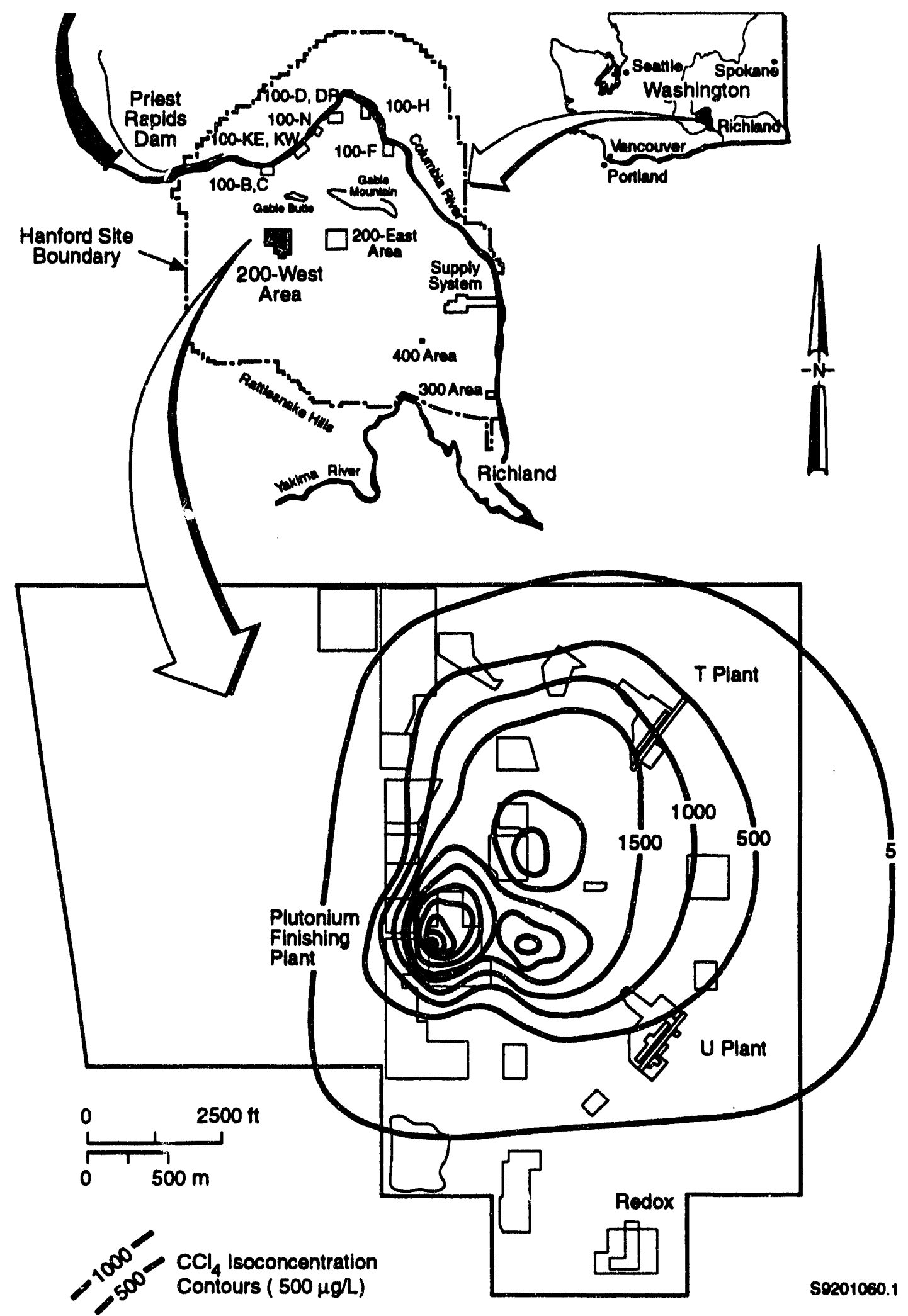

Figure A.1 Carbon Tetrachloride Groundwater Plume at Hanford's 200 West Area 


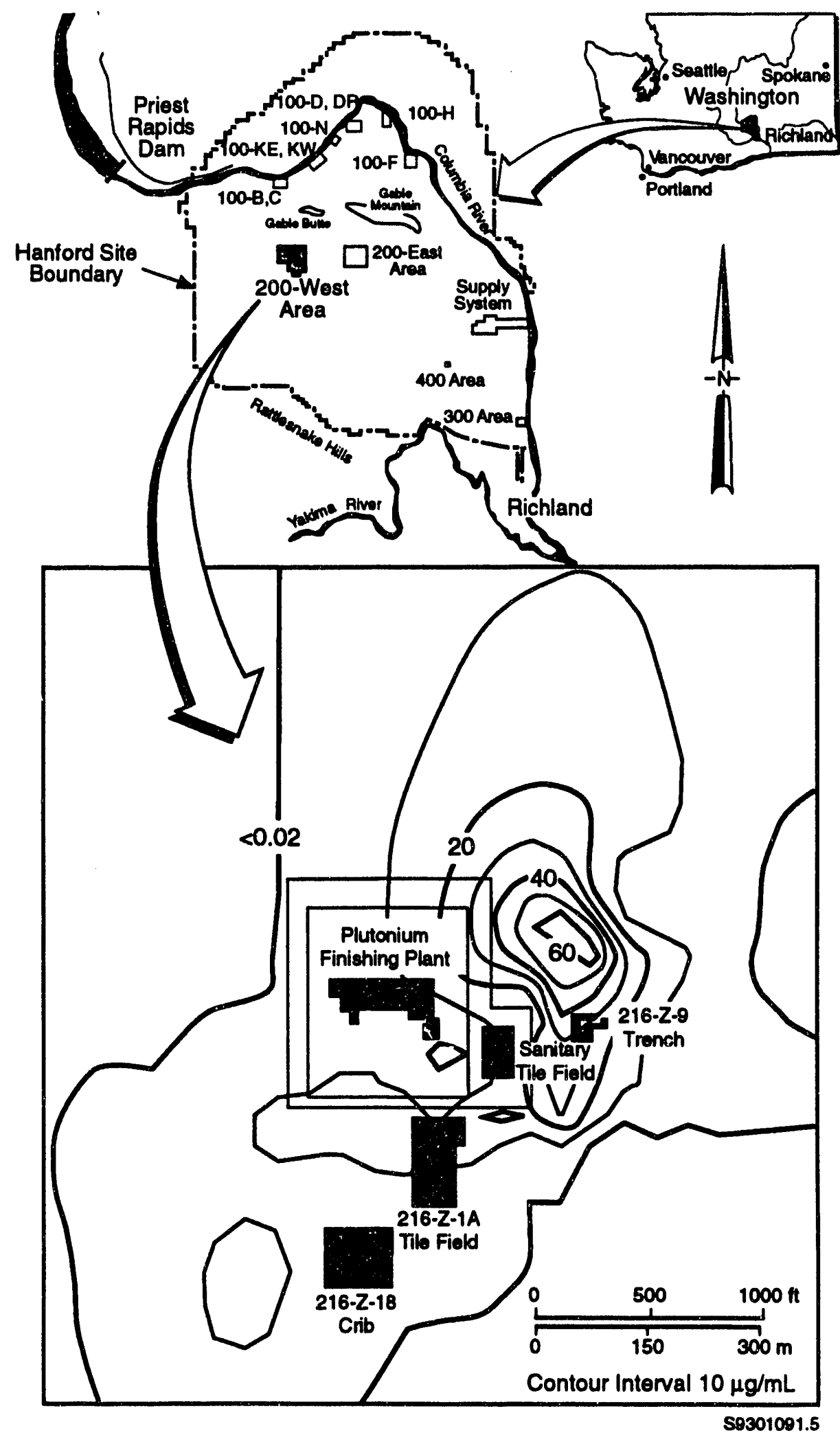

Figure A.2 Contour Map of Carbon Tetrachloride Concentrations in Soil Gas at Hanford's 200 West Area - May 1992 


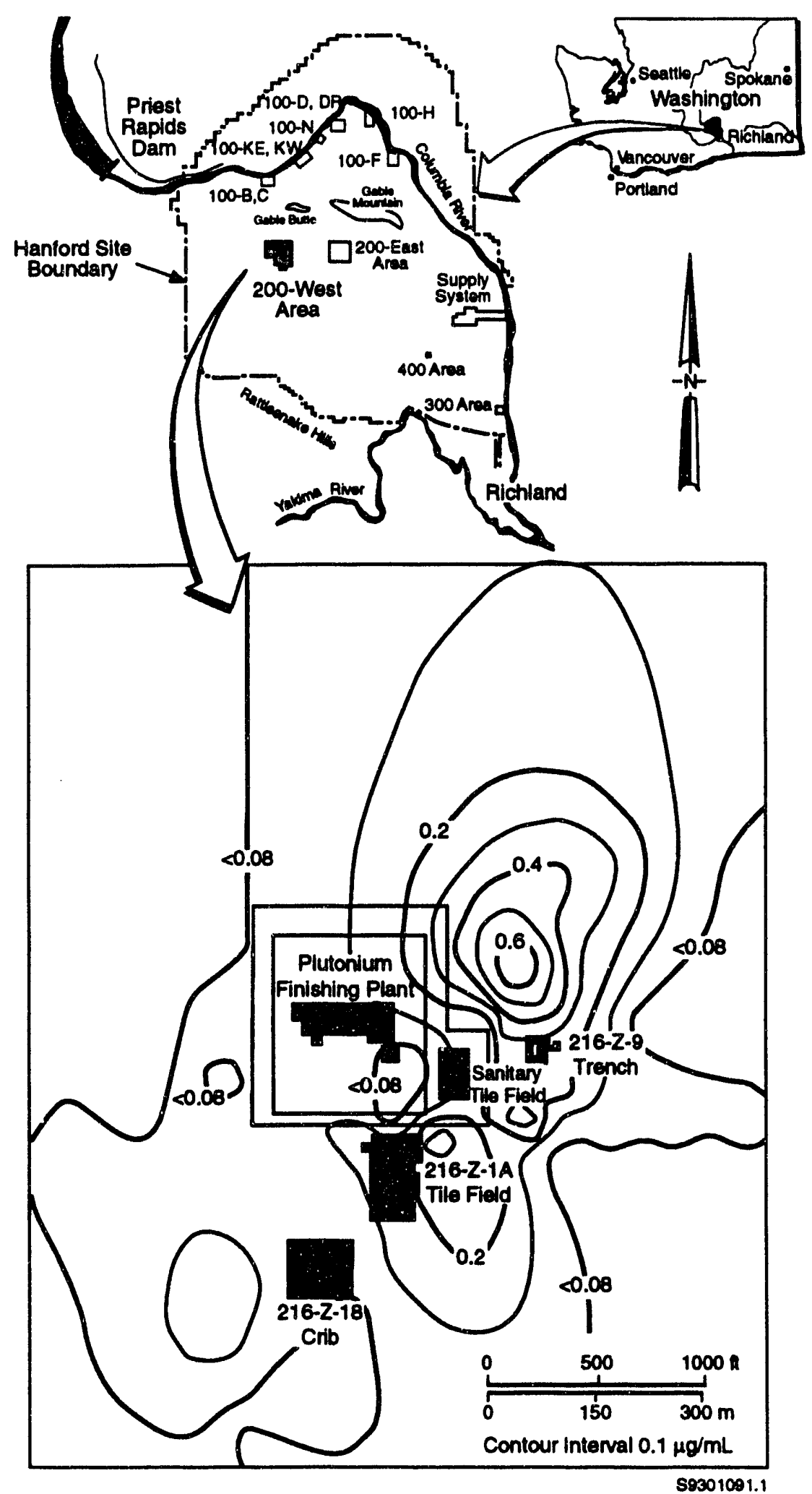

Figure A.3 Contour Map of Chloroform Concentrations in Soil Gas at Hanford's 200 West Area - May 1992 


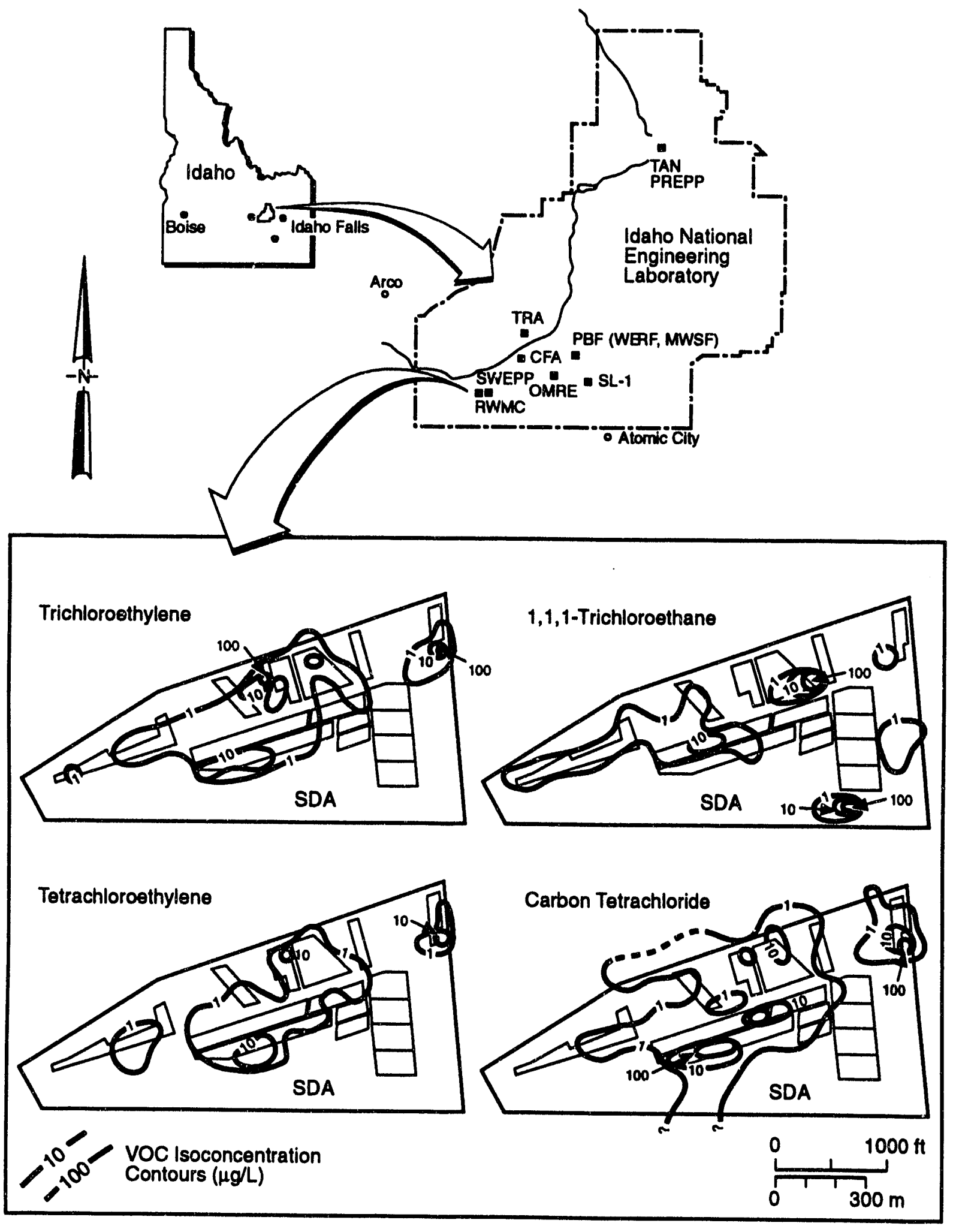

$\begin{aligned} \text { S9201060.6 } & \end{aligned}$

Figure A.4 Volatile Organic Compound Vadose Zone Plumes at Idaho's Radioactive Waste Management Complex 
$\mathrm{CCl}_{4}, 147,627 \mathrm{~L}(39,000$ gal) of lubricating oil, and $94,633 \mathrm{~L}(25,000 \mathrm{gal})$ of other organic compounds (trichloroethane, TCE, tetrachloroethylene, toluene, and berizene). The VOCs in perched water at the Idaho site are shown in Figure A.5. Current data sliagest that the confined aquifer has not been contaminated.

\section{Test Area North}

The Test Area North/Technical Support Facility injection well received low-level radioactive waste, process waste waters, and treated sanitary sewage. Suspected constituents disposed include mercury, lead, chromium, chlorinated solvents (e.g., TCE), and radionuclides $\left(e .9 .,{ }^{80} \mathrm{Sr},{ }^{134} \mathrm{Cs},{ }^{137} \mathrm{Cs}\right)$. Concentrations of VOCs at the bottom of the injection well have been measured at 35,000 $\mu \mathrm{g} / \mathrm{L}$. Discharge has been into the Snake River Plain aquifer, creating a TCE plume estimated to be $1.6 \mathrm{~km}(1$ mile) wide and $3.2 \mathrm{~km}$ (2 miles) long. TCE concentration at the plume front has been measured at $7.5 \mu \mathrm{g} / \mathrm{L}$ (Figure A.6).

\section{Lawrence Livermore National Laboratory}

\section{Main Site}

The VOC contamination in groundwater includes approximately $85 \%$ of Livermore's Main Site and covers a total of $3.4 \mathrm{~km}^{2}\left(1.3 \mathrm{mi}^{2}\right)$ (involving areas of offsite contamination). A main source of the VOC contamination is believed to have been aircraft service operations conducted between 1942 and 1951 during Livermore Naval Air Station's and its successors' occupancy of the site. Offsite areas of contamination include a plume that extends $762 \mathrm{~m}$ (2500 ft) to the west onto private property and another plume $244 \mathrm{~m}$ $(800 \mathrm{ft})$ south of the southeastern portion of the site onto U.S. Department of Energy property administered by Sandia National Laboratories (Figure A.7). The predominant VOC in the groundwater is TCE, exceeding $1,000 \mu \mathrm{g} / \mathrm{L}$ in the eastern site, with significant concentrations of tetrachloroethylene also present. Smaller quantities of six other chlorinated hydrocarbons (1,1-dichloroethylene, 1,2-dichloroethylene, 1,1-dichloroethane, 1,2-dichloroethane, $\mathrm{CCl}_{4}$, and chloroform) have been identified in the groundwater. The concentrations of VOCs in the vadose zone have been measured predominantly in the range of $<5$ to $500 \mu \mathrm{g} / \mathrm{L}$, with levels exceeding $1000 \mu \mathrm{g} / \mathrm{L}$ in one area only. In some areas, VOC contamination is accompanied by fuel hydrocarbon contamination of the vadose zone (up to $11,000 \mu \mathrm{g} / \mathrm{mL}$ total fuel hydrocarbons) and groundwater $(0.001$ to $100 \mu \mathrm{g} / \mathrm{mL}$ total fuel hydrocarbons). Tritium (900 to $20,000 \mathrm{pCi} / \mathrm{L}$ ), chromium, and lead have been identified in groundwater in isolated areas of the site. 


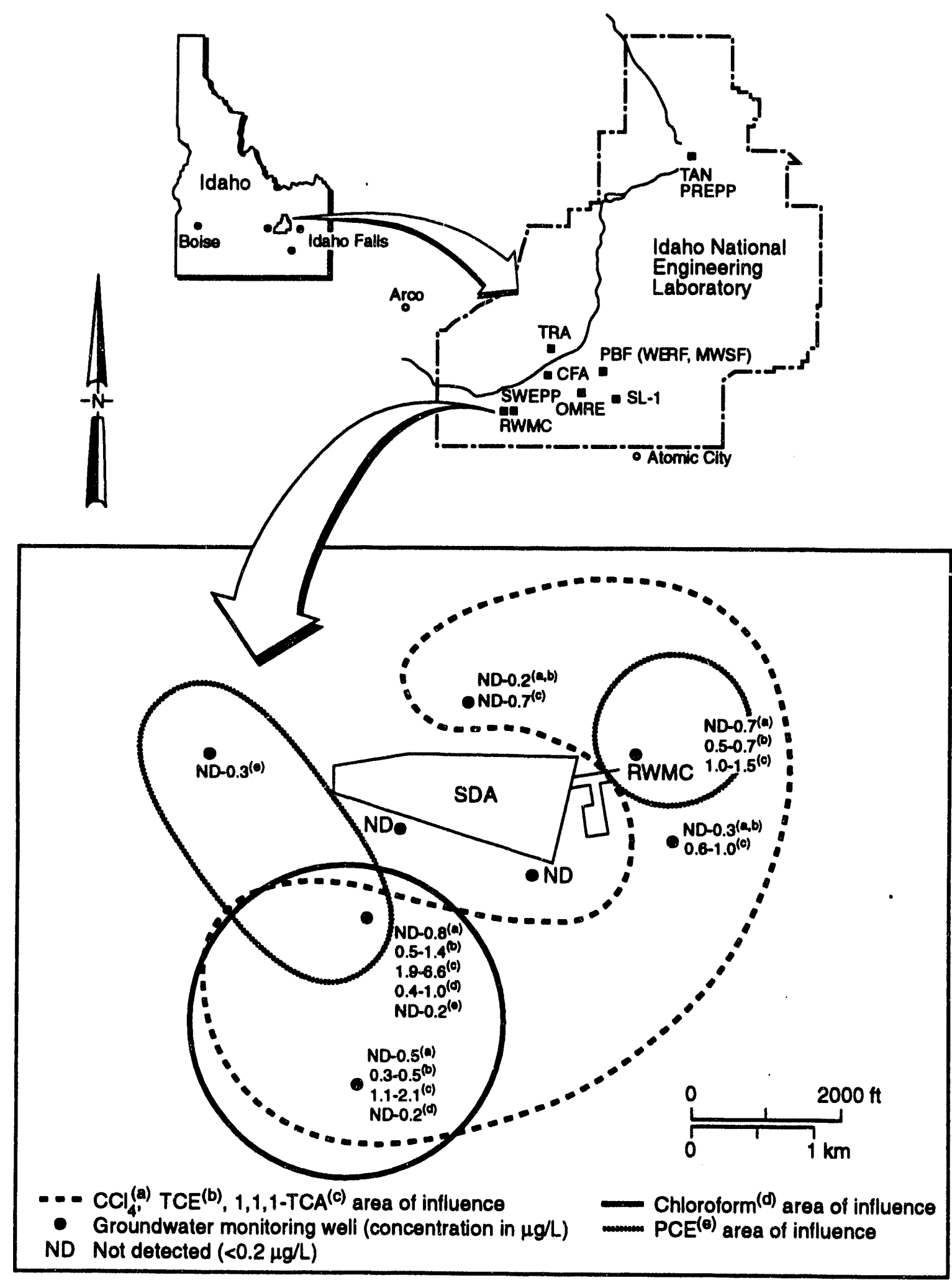

S9201060.5

Figure A.5 Volatile Organic Compound Areas of Influence in Perched Water at Idaho's Radioactive Waste Management Complex 


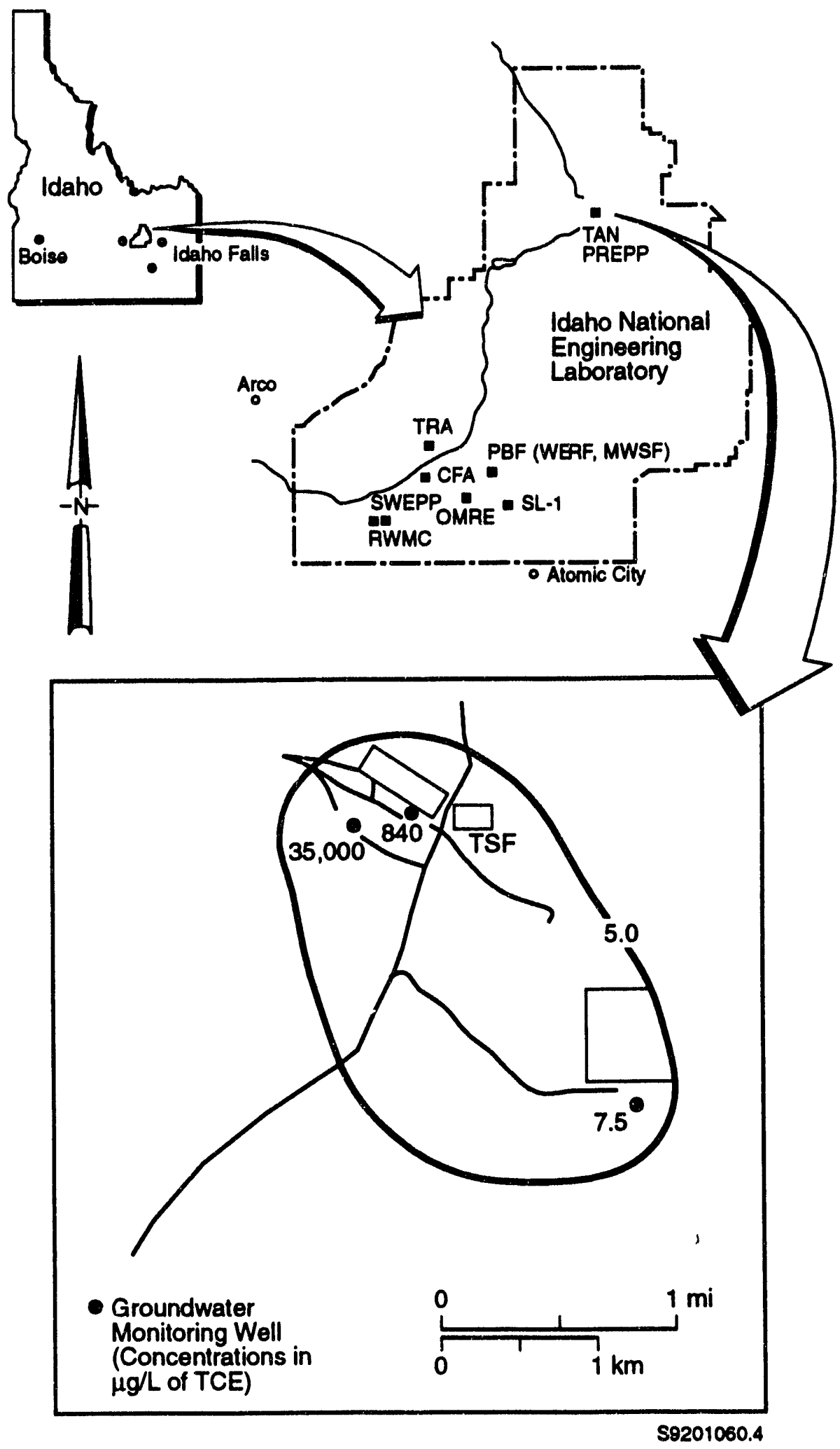

Figure A.6 Trichloroethylene Groundwater Plume at Idaho's Test Area North 


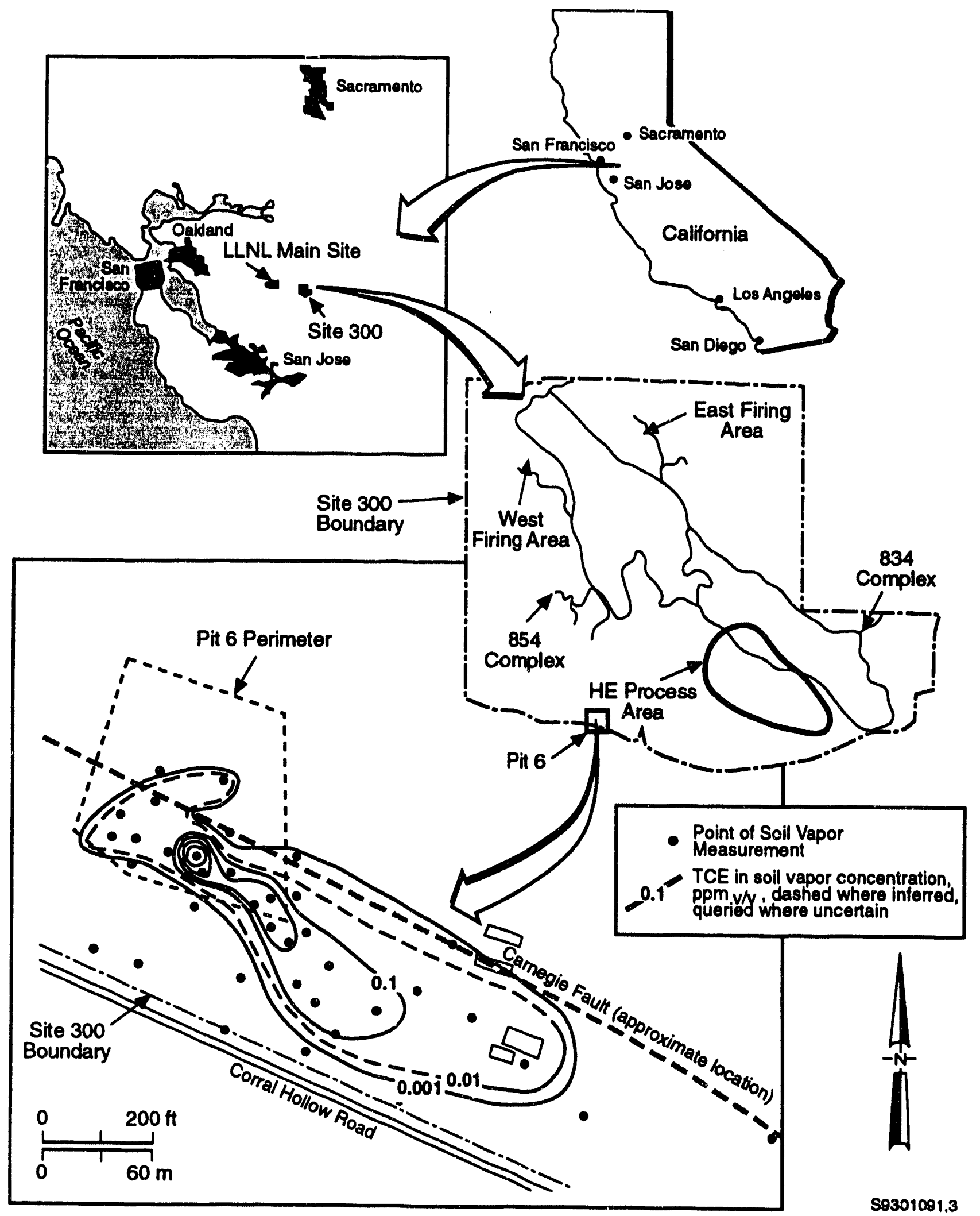

Figure A.7 Volatile Organic Compound Groundwater Plume at Livermore's Main Site 


\section{Site 300}

\section{Complax}

The 834 Complex has been the source of leakage of TCE and other oily organic co-contaminants for a number of years into the surrounding ground. Vadose zone contamination consists of an approximate 4.3-m (14-ft) interval, $7.6 \mathrm{~m}(25 \mathrm{ft})$ below the surface, and approximately $91 \mathrm{~m}(300 \mathrm{ft})$ in diameter. The lower portion of soil contamination lies in perched water. The perched water plume extends approximately $0.4 \mathrm{~km}$ $(0.25 \mathrm{mi})$ southwest of the 834 Complex, with VOC concentrations exceeding $100,000 \mu \mathrm{g} / \mathrm{L}$ at a distance of $122 \mathrm{~m}$ (400 ft) from the complex (Figure A.8). The perched water zone is bounded underneath by a dense clay layer, and there is no evidence of TCE migration through this clay layer to the underlying regional aquifer.

\section{Landfill Pit 6}

Landfill Pit 6 received organic, inorganic, and radioactive wastes for 9 years. Vadose zone contamination included polychlorinated biphenyls (PCBs) and other organic chemicals, beryllium, mercury, depleted uranium, and miscellaneous radioisotopes. Depth to the water-bearing zone underlying the pit averages $9.1 \mathrm{~m}$ (30 ft), with an average zone thick-

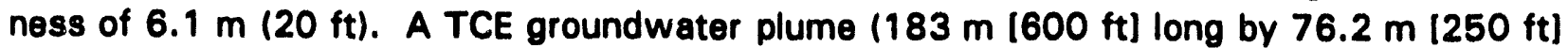
wide), moving at a rate of $45 \mathrm{~m} / \mathrm{yr}(148 \mathrm{ft} / \mathrm{yr})$ emanates from the southeastern corner of the pit (Figure A.9). The highest concentration of TCE measured in groundwater has been $250 \mu \mathrm{g} / \mathrm{L}$. Other chlorinated hydrocarbons detected include tetrachloroethylene and 1,2-dichloroethylene. Significant concentrations of other organics (e.g.. PCBs, explosives, fuel hydrocarbons), uranium, other inorganic constituents, and radioisotopes have not been detected in the groundwater. TCE has been detected in core samples as deep as $7.7 \mathrm{~m}$ $(25.4 \mathrm{ft})$, with highest concentrations $(330$ and $450 \mu \mathrm{g} / \mathrm{kg})$ at 1.8 and $2.7 \mathrm{~m}(6$ and $9 \mathrm{ft}$ ), respectively. The distribution of TCE in the soil vapor (Figure A.10) closely resembles the distribution found in the groundwater. The maximum concentration of TCE detected in the soil gas was $160 \mu \mathrm{g} / \mathrm{mL}$. The chlorinated hydrocarbons detected in the soil gas were tetrachloroethylene, $3.4 \mu \mathrm{g} / \mathrm{mL} ; 1,1,1$-trichloroethane, $0.61 \mu \mathrm{g} / \mathrm{mL} ; 1,2$-dichloroethane, $0.042 \mu \mathrm{g} / \mathrm{mL} ; 1,1$-dichloroethylene, $8.93 \mu \mathrm{g} / \mathrm{mL}$; and 1,2-dichloroethylene, $0.003 \mu \mathrm{g} / \mathrm{mL}$.

\section{Los Alamos National Laboratory}

Technical Area 54 served as the Los Alamos principal chemical waste disposal area from 1964 to 1985 . Liquid wastes were disposed to a pit, and containerized wastes (with and without adsorbents) were disposed in 34 shafts 10.9 to $2.4 \mathrm{~m}$ [ 3 to $8 \mathrm{ft}$ ] dia. and $18.3 \mathrm{~m} \mathrm{[60} \mathrm{ft]} \mathrm{deep)} \mathrm{and} \mathrm{spaced} 4.6 \mathrm{~m}(15 \mathrm{ft})$ apart. Waste disposal logs indicate that the 


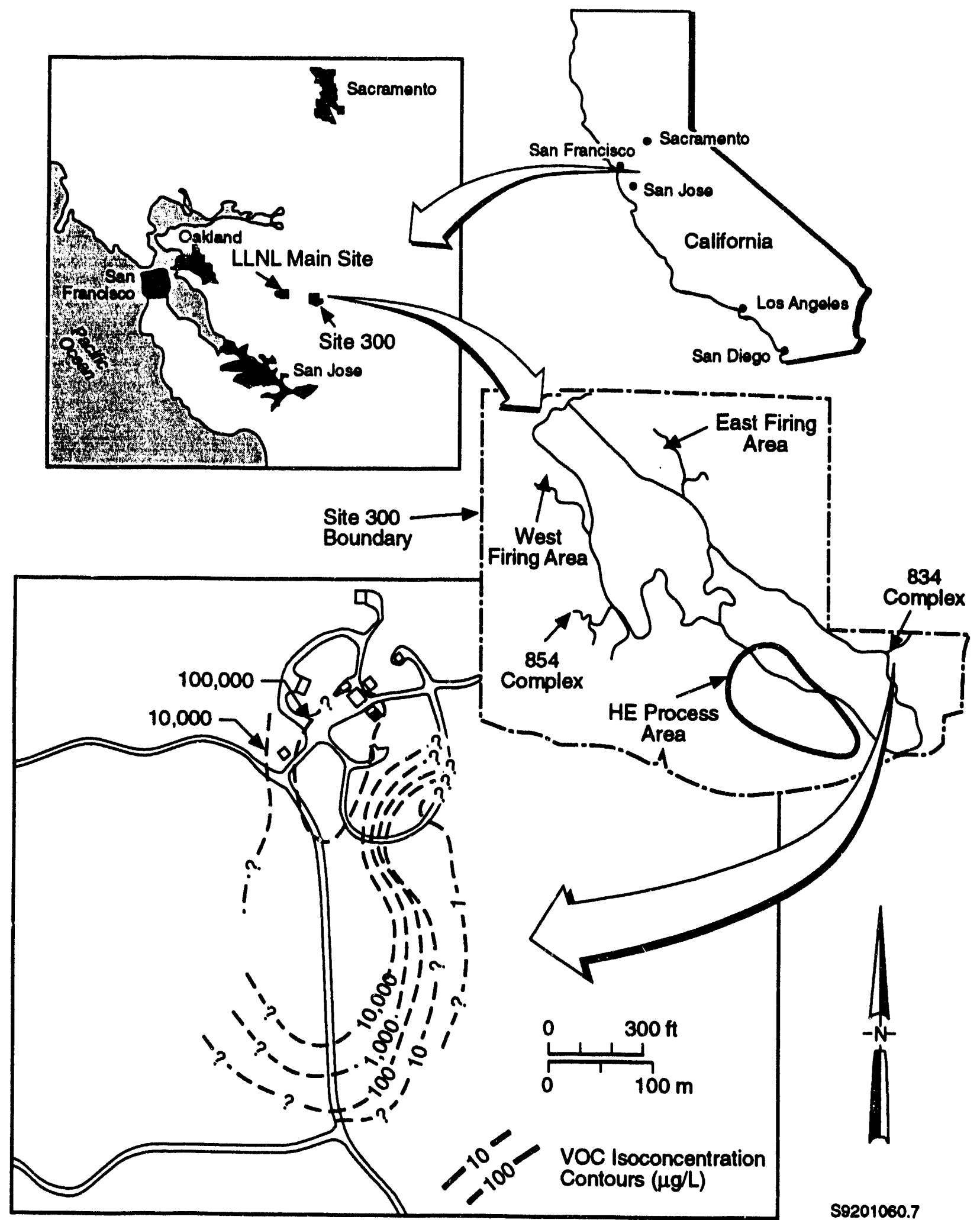

Figure A.8 Volatile Organic Compound Vadose Zone Plume at Livermore's 834 Complex 


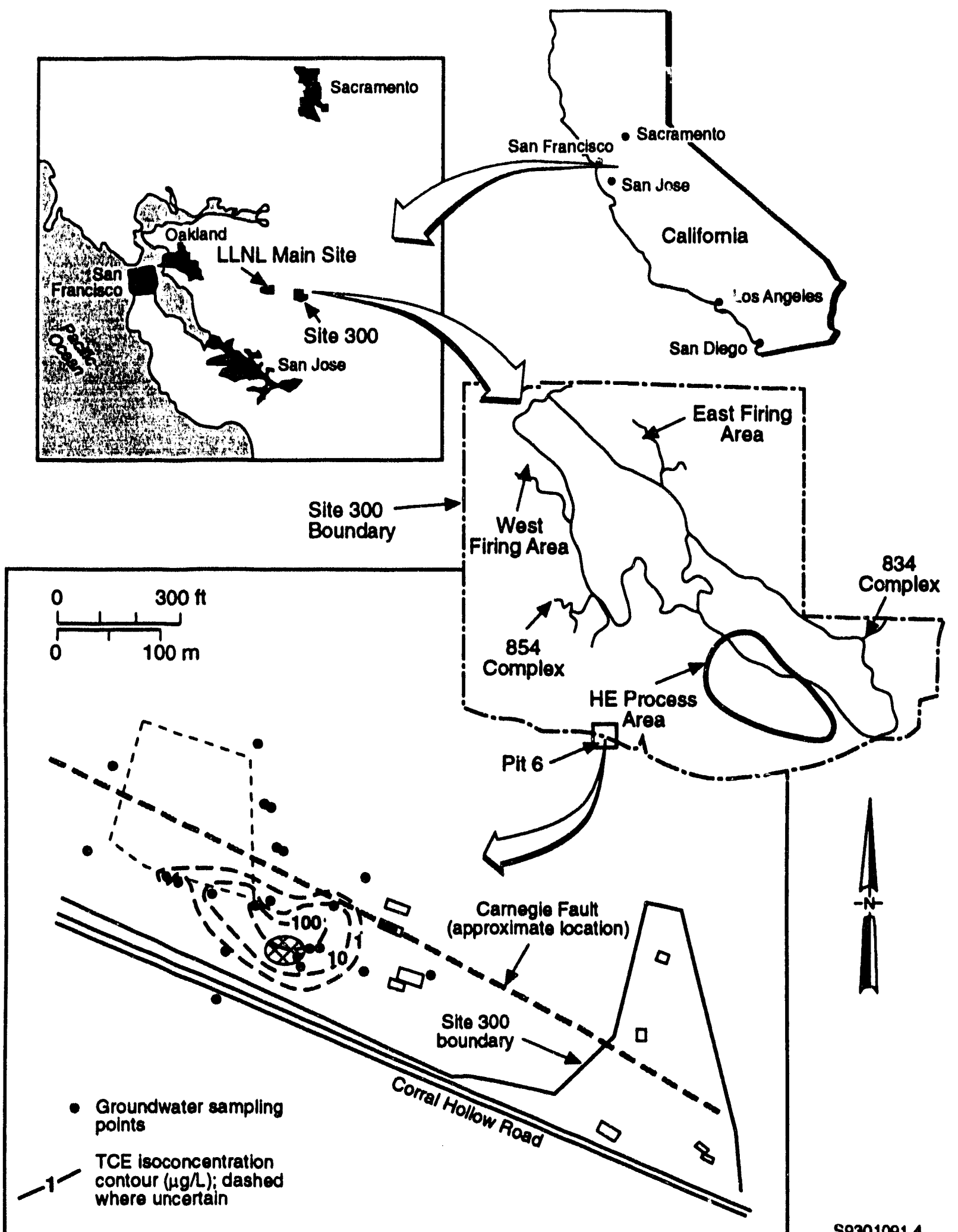

$\mathbf{5 9 3 0 1 0 9 1 . 4}$

Figure A.9 Contour Map of Trichloroethylene Concentrations in Groundwater at Livermore's Landfill Pit 6 


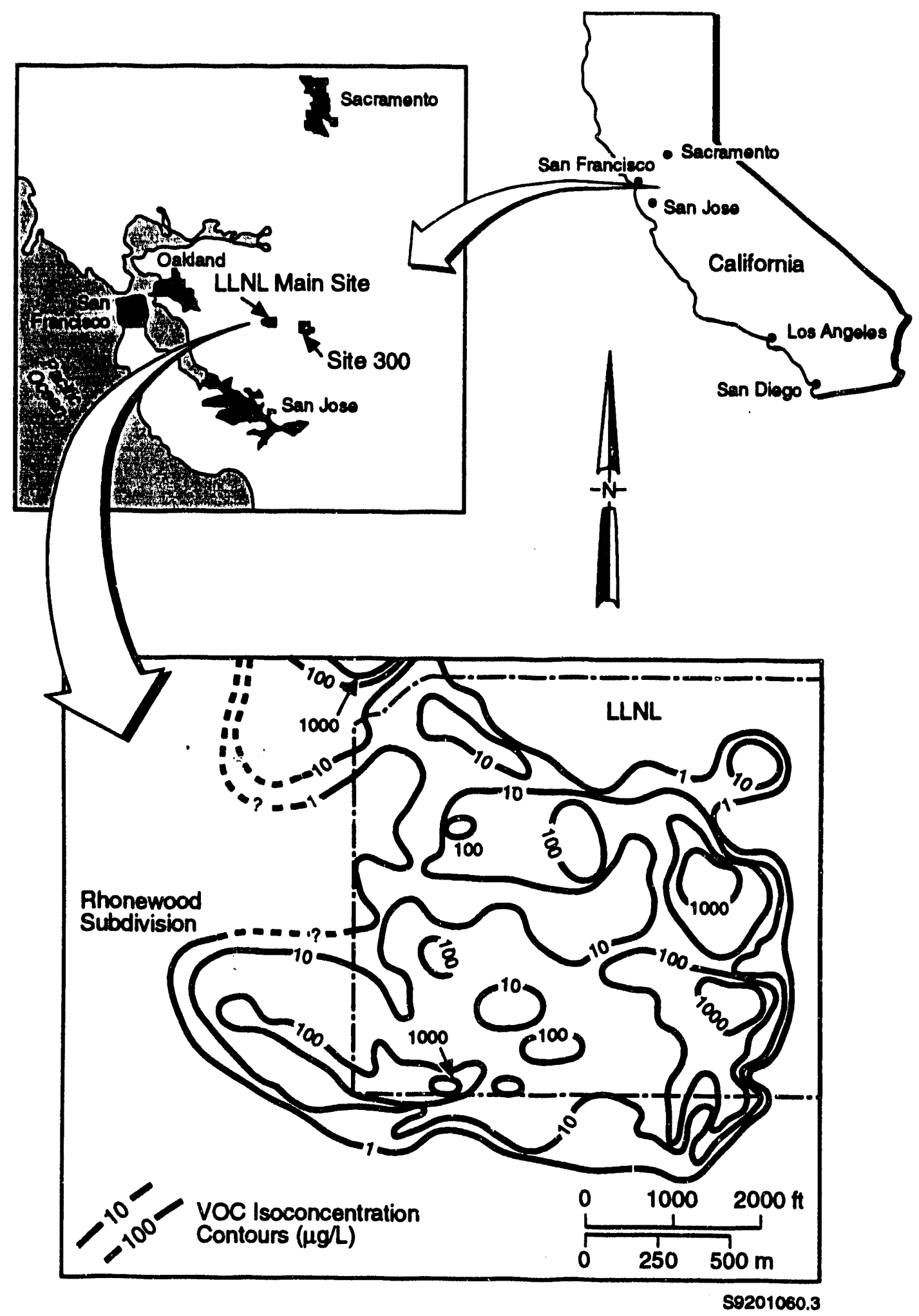

Figure A.10 Contour Map of Trichloroethylene Concentrations in Soil Vapor at Livermore's Landfill Pit 6 
amounts disposed to individual shafts ranged from 798 to $15,505 \mathrm{~kg}(1762$ to $34,227 \mathrm{lb})$. VOCs have been detected in rock core and pore gas samples $(\theta .9 ., 171 \mu \mathrm{g} / \mathrm{mL}$ TCE) (Figure A.11). Aqueous transport of contaminants by unsaturated flow is not considered a viable mechanism for contaminant migration at this site. Near-vertical fractures in the tuff are often partially or completely filled with caliche, brown clay, or lemonitic material, thus reducing the potential for fractures as the major vertical pathway for contaminant transport. It is currently speculated that VOC vapor transport, from source term to intersecting shafts via laterally permeable surge beds, with subsequent movement downward through the open borehole, may be a major pathway of further movement of VOCs both horizontally and vertically at this site.

\section{Nevada Test Site}

During the course of testing operations, wastes have been disposed in 18 sumps and injection wells located in 7 areas on the Nevada Test Site and may be point sources of groundwater contamination (Area 15 EPA Farm Complex, Area 4 BJY Race Sump, Area 3 UD-6 Disposal Holes, Area 3 Core Storage Yard, Area 3 Subdock Complex, Area 9 U9Y Crater, and Area 8 U8d Crater). Contaminants disposed include tritium, plutonium, cesium, strontium, radioactive iodine; heavy metals; solvents, containing VOCs; potential PCBs; and semivolatiles. There are also eight abandoned or inactive leach fields (Area 6 CP2 and CP6; Area 23 Building 155; Area 25 R-MAD, E-MAD, Test Cells A, and C; Area 26 Building 401 ) that are known to have received radioactive wastes and are suspected to have received mixed wastes. Known or suspected contaminants include radionuclides, chemical solvents, and degreasing agents, including caustics and acids. Initiation of environmental restoration activities for these areas is planned for the 1992-1994 time frame.

\section{Pantex Plant}

Zone 12 of the Pantex Plant, consisting of 200 acres located in the eastern portion of the site, is the subject of a groundwater contamination assessment. Historical activities at this site have led to spills and discharges of solvents, metals, pesticides, PCBs, petroleum hydrocarbons, acids, inorganics, and high-explosive waste water. Total BTEX concentrations in the soils have been reported in the range of 25,000 to $250,000 \mu \mathrm{g} / \mathrm{kg}$. Analyses of water from wells drilled into a zone of perched water underlying the area at a depth of 62.5 to $85.3 \mathrm{~m}$ (205 to $280 \mathrm{ft}$ ) indicate the presence of various metals, volatiles, and high explosives. There is at this time no evidence of contamination in the Ogallala aquifer, located at a depth of approximately $128 \mathrm{~m}(420 \mathrm{ft})$ below ground surface. TCE has been measured in a concentration range of 10 to $17 \mu \mathrm{g} / \mathrm{L}$ in the perched water. The possible source of this TCE contamination is a leaking underground waste oil storage tank. 


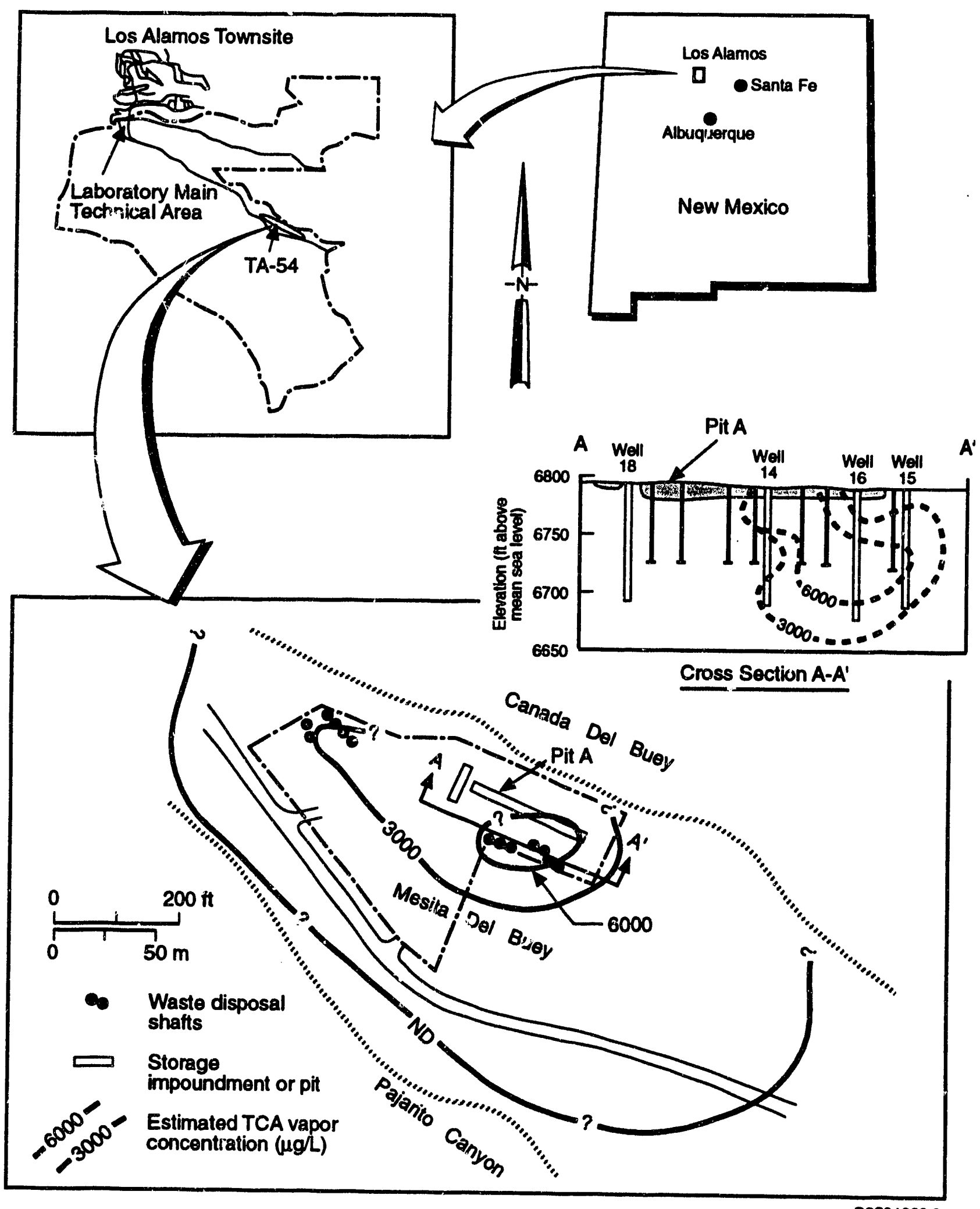

$\mathbf{5 9 2 0 1 0 6 0 . 8}$

Figure A.11 Trichloroethane Plume in the Vadose Zone at Los Alamos Test Area 54 


\section{Rocky Flats Plant}

\section{Operable Unit 1}

Rocky Flats' Operable Unit 1 (881 Hillside) was an area used for barrel waste storage. VOCs have contaminated the underlying shallow groundwater. TCE, tetrachloroethylene, 1,1,1-trichloroethane, and 1,1-dichloroethylene have been detected at levels up to 13,000, $5900,19,000$, and $13,000 \mu \mathrm{g} / \mathrm{L}$, respectively. Concentrations of VOCs in groundwater drop significantly ( $<5 \mu \mathrm{g} / \mathrm{L}$ ) within $61 \mathrm{~m}(200 \mathrm{ft}$ ) of the original area of storage. Abovebackground levels of nickel, strontium, selenium, zinc, and uranium also have been detected in the groundwater.

\section{Operable Unit 2}

Operable Unit 2, consisting of the 903 Pad, Mound Area, and East Trenches, was used as a storage and disposal area. Waste materials stored in the area (903 Pad) included radioactively and chemically contaminated (e.g., plutonium, uranium, and $\mathrm{CCl}_{4}$ ) machine and cutting oils. The 903 Pad is probably one of several storage sites that has led to the contamination of the underlying groundwater. The VOC plume in this area is best described by the distribution of TCE contamination that extends approximately $183 \mathrm{~m}$ $(600 \mathrm{ft}$ ) southeast and $457 \mathrm{~m}$ (1500 ft) northeast of the $903 \mathrm{Pad}$ (Figure A.12). Concentrations of VOCs measured in the shallow bedrock groundwater include 96,000 $\mu \mathrm{g} / \mathrm{L}$ TCE, $45,000 \mu \mathrm{g} / \mathrm{L}$ perchlorethylene, and $1100 \mu \mathrm{g} / \mathrm{L} \mathrm{CCl}_{4}$. Above-background levels of selected inorganic (e.g., strontium, barium, copper, and nickel and, to a lesser extent, chromium, manganese, selenium, lead, zinc, and molybdenum) and radioactive (predominantly ${ }^{238} U$, with lower concentrations of americium and plutonium) constituents are also present in the groundwater. Current data suggest that the confined bedrock groundwater system has not been impacted.

\section{Operable Unit 4}

Releases of contaminants to Operable Unit 4 (solar evaporation nonds) include primarily nitrate/nitrite, radionuclides, and VOCs. Nitrate concentrations as high as $12,100 \mathrm{mg} / \mathrm{L}$ have been detected in wells on the northern side of the ponds. The highest concentrations of uranium (428 pCi/L) and tritium (9000 pCi/L) have been detected on the eastern side of the ponds. The VOCs have been detected in shallow wells southeast of the ponds (e.g., vinyl chloride, $950 \mu \mathrm{g} / \mathrm{L}$ ). Low concentrations of VOCs (i.e., acetone, $110 \mu \mathrm{g} / \mathrm{kg}$; chloromethane, $52 \mu \mathrm{g} / \mathrm{kg}$; dichloromethane, $29 \mu \mathrm{g} / \mathrm{kg}$ ) have been detected in pond sediments. The ponds were historically used to store/evaporate various process aqueous wastes, including those with low-level radioactivity, high nitrates, acids, and aluminum hydroxide. 


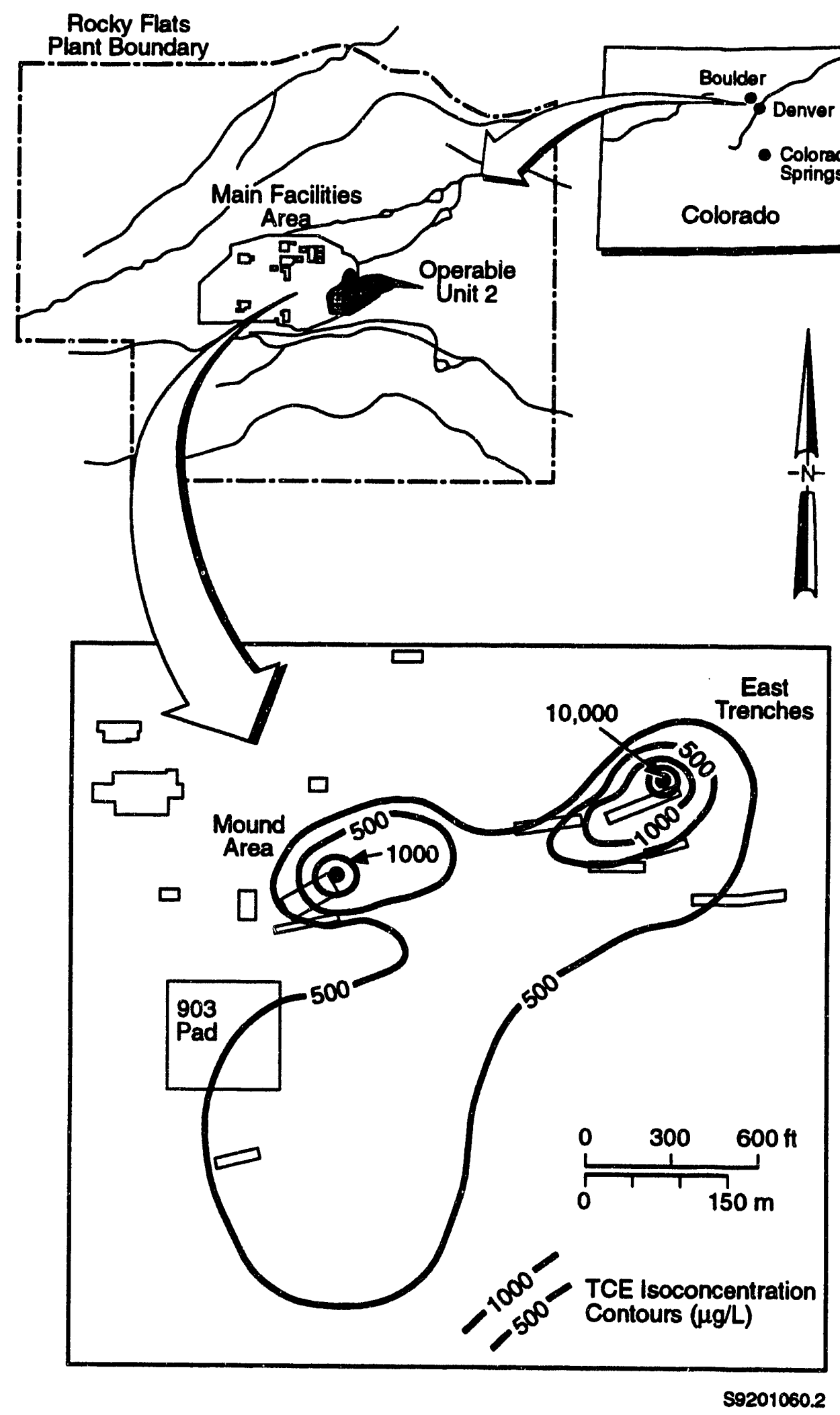

Figure A.12 Trichloroethylene Plume in Groundwater at Rocky Flats' Operable Unit 2 


\section{Sandia National Laboratories}

The Mixed Waste Landfill Integrated Demonstration at Sandia is focused on integrating new and emerging technologies and conventional methods to characterize heavy metal contaminant sources (source characterization and plume definition) and contaminant migration beneath landfills. The Sandia demonstration has targeted two sites (approximately 0.8 hectare [2 acres] each) for technology demonstration: 1) the Chemical Waste Landfill, in which the waste forms include acids, reactives, organics (e.g., TCE and TCE mixes), and metals (chromium, beryllium, mercury, arsenic, lead, cadmium, and antimony) and 2) the Mixed Waste Landfill, in which the wa forms include approximately $2832 \mathrm{~m}^{3}\left(100,000 \mathrm{ft}^{3}\right)$ of transuranic, uranium/thorium, fission products, tritiumcontaining and -induced activity wastes, and Resource Conservation and Recovery Act of 1976-regulated wastes (metals and acids). Previous characterization activities at the Chemical Waste Landfill have revealed chromium to a depth of $23 \mathrm{~m}(75 \mathrm{ft}$ ) beneath one disposal cell. TCE has been detected in groundwater underlying the site at low levels $(20 \mu \mathrm{g} / \mathrm{L})$. At the Mixed Waste Landfill, tritium has been detected in the underlying soil to a depth of approximately $30 \mathrm{~m}$ (100 ft). Currently, no contamination of the groundwater underlying the Mixed Waste Landfill has been detected. 


\section{Appendix B}

\section{Bibliography}




\title{
Appendix B
}

\author{
Bibliography
}

\section{Hanford Site}

Last, G. V., and V. J. Rohay. 1999. Carbon Tetrachloride Contamination, 200 West Area, Hanford Site. PNL-SA-19564, Pacific Northwest Laboratory, Richland, Washington.

Rohay, V. J., G. V. Last, V. L. King, and L. A. Doremus. 1992. FY92 Site Characterization Status Report and Data Package for the Carbon Tetrachloride Site. WHC-SD-EN-TI-063, Rev. 0, prepared by V. J. Rohay and V. L. King, Westinghouse Hanford Company, and G. V. Last and L. A. Doremus, Pacific Northwest Laboratory, for Westinghouse Hanford Company, Richland, Washington.

\section{Idaho National Engineering Laboratory}

Cannon, P. G., K. M. Kostelnik, and K. J. Owens. 1993. Buried Waste Integrated Demonstration Fiscal Year 1992 Close-Out Report. EGG-WTD-10612, Idaho National Engineering Laboratory, EG\&G Idaho, Inc., Idaho Falls, Idaho.

EG\&G Idaho. 1988. Informal Report, RCRA Facility Investigation Work Plan for TAN Groundwater. EGG-ER-8084, Revision 1, Idaho Falls, Idaho.

Idaho National Engineering Laboratory. 1989. Remedial Investigation/Feasibility Study Work Plan for the Subsurface Disposal Area, Radioactive Waste Management Complex at the INEL. EGG-WM-8776, EG\&G Idaho, Inc., Idaho Falls, Idaho.

Kostelnik, K. M. 1993. Buried Waste Integrated Demonstration (BWID) Fiscal Year 1994 (FY94) Technology Needs - KMK-10-93. Idaho National Engineering Laboratory, Idaho Falls, Idaho.

\section{Lawrence Livermore National Laboratory}

Isherwood, W. F., C. H. Hall, M. D. Dresen, A. Boegel, J. Daniels, R. Devany, E. Nichols, D. Rice, R. Thorpe, and B. Toler. 1990. CERCLA Feasibility Study for the LLNL-Livermore Site. UCRL-AR-104040, Draft, Lawrence Livermore National Laboratory, University of California, Livermore, California. 
Ruggieri, M. R., D. W. Carpenter, N. B. Crow, M. J. Taffet, J. A. Oberdorfer, and A. L. Lamarre. 1987. LLNL Site 300 Erivironmental Investigations Quarterly. UCAR-10194-87-3, Lawrence Livermore National Laboratory, University of California, Livermore, California.

Taffet, M. J. 1990. Draft Remedial Investigation of Landfill Pit 6, Lawrence Livermore National Laboratory Site 300. UCRL-ID-103961. Environmental Restoration Division, Lawrence Livermore National Laboratory, University of California, Livermore, California.

Yow, J. L., Jr. 1991. Environmental Technology Program, Annual Report, FY 90. UCRL-LR-105199, Lawrence Livermore National Laboratory, Livermore, California.

\section{Los Alamos National Laboratory}

Environmental Surveillance Group. 1989. Environmental Surveillance at Los Alamos During 1988. LA-11628-ENV, Los Alamos National Laboratory, Los Alamos, New Mexico.

IT Corporation. 1987. Hydrogeologic Assessment of Technical Area 54, Areas G\&L, Project No. 301017-02. Los Alamos National Laboratory, Los Alamos, New Mexico.

IT Corporation. 1992. RCRA Facility Investigation Work Plan. OU 1148, Rev. O, Draft, Los Alamos, New Mexico.

\section{Nevada Test Site}

DOE. 1989. Site Specific Plan, Nevada Test Site. DOE/NV--336, U.S. Department of Energy, Las Vegas, Nevada.

\section{Pantex Plant}

ADS 1198 A and 1199 9. Background Information. Unit Groups, Pantex Plant, Amarillo, Texas.

DOE. 1989. Environmental Restoration Program, Remedial Investigation Report, Task 1, Stage 1, Pantex Plant, Amarillo, Texas (Draft). U.S Department of Energy, Albuquerque Operations Office, Los Alamos National Laboratory, Albuquerque, New Mexico. 
Purtymun, W. D., N. M. Becker, and M. Maes. 1982. Supplementary Documentation for an Environmental Impact Statement Regarding the Pantex Plant, Geohydrologic Investigations. LA-9445-PNTX-H, Los Alamos National Laboratory, Los Alamos, New Mexico.

\section{Rocky Flats Plant}

Costain, D. B., T. A. Moore, R. Ladman, and D. Cirrincione. 1990. Rucky Flats Plant Site Environmental Report For 1989. RFP-ENV-89, EG\&G Rocky Flats, Inc., Golden, Colorado.

Costain, D., D. A. Cirrincione, R. W. Ladman, N. R. Stallcup, and D. R. Stanton. 1991. Rocky Flats Plant Site Environmental Report for 1990. RFP-ENV-90, EG\&G Rocky Flats Plant, Golden, Colorado.

DOE. 1990. Draft Treatability Studies Plan, EG\&G Rocky Flats Environmental Restoration Program. U.S. Department of Energy, Rocky Flats Plant, Golden, Colorado.

EG\&G Rocky Flats Plant. 1991. Draft Final Groundwater Protection and Monitoring Plan. Golden, Colorado.

\section{Sandia National Laboratories}

Berry, D. L. 1991. Organic/Inorganic Vadose-Zone Landfill Integrated Technology Demonstration: Assessment of Feasibility (Draft). Sandia National Laboratories, Albuquerque, New Mexico.

Purvis, S. T. 1992. Mixed Waste Landfill Integrated Demonstration Technology Needs. Sandia National Laboratories, Albuquerque, New Mexico.

Tyler, L. D. 1991. SNL Mixed Waste Landfill ID Request for Proposal Package. Sandia National Laboratories, Albuquerque, New Mexico.

\section{Other}

Chem-Nuclear Geotech, Inc. 1991. Technology Needs and Assessment Final Report. DOE/ID/12584-92, Vols. 1 and 2, GJPO-104, U.S. Department of Energy, Idaho Field Office, Grand Junction, Colorado. 
Junk, G. A. 1992. Characterization-Monitoring Technology Projects for Volatile Organic Compounds (VOCs), VOC Vadose Zone/Groundwater Characterization Technologies, T7;" CH-1211-01, Arid-VOC 1D, Subtask 3. Prioritization of Technology Projects. Ames Laboratory, Institute for Physical Research and Technology, lowa State University, Ames, lowa. 


\section{Distribution}

No. of

Conies

\section{OFFSITE}

12 DOE/Office of Scientific and Technical Information

6 U.S. Department of Energy 12800 Middlebrook Road Germantown, MD 20874

T. D. Anderson, EM-551

D. Biancosino, EM-551

M. K. Harmon, EM-442

J. C. Lehr, EM-442

S.C.T. Lien, EM-54

M. W. Shupe, EM-541

U.S. Department of Energy 1000 Independence Ave. S.W. Washington, D.C. 20585

C. W. Frank, EM-50

U.S. Department of Energy Amarillo Area Office HGWY 60 FM 2373 - Pantex Plant Amarillo, TX 79120

T. Taylor

2 U.S. Department of Energy Savannah River Field Office P.O. Box A

Aiken, SC 29808

D. Kaback

J. L. Steele

2 Argonne National Laboratory 9700 S. Cass Avenue Argonne, IL 60439-4837
J. E. Helt
R. Peters

No. of

Copies

Ames Laboratory 329 Wilhelm Hall

lowa State University

Ames, IA 50011

J. Corones

Brookhaven National Laboratory

Building 703-50 Rutherford

Upton, NY 11973

P. Colombo

Chem-Nuclear Geotech, Inc.

P.O. Box 14000

Grand Junction, CO 81502-2567

R. Walker

3 Ebasco Services, Inc.

1201 Jadwin, Suite 202

Richland, WA 99352

R. J. Cameron

B. B. Peters

R. Treat

9 EG\&G Idaho, Inc.

Idaho National Engineering

Laboratory

P.O. Box 1625

Idaho Falls, ID 83415

T. Chalwin

J. Conner

L. Hull

K. Koller

K. M. Kostelnik

R. MacKinnon

W. Shutte

R. R. Stiger

W. Sullivan 
No. of

ropies

4 EG\&G Inc.

Rocky Flats Plant

P.O. Box 464

Golden, CO 80402

J. Blakesleo

E. Dille

S. Grace

T. Greengard

EG\&G Energy Measurements, Inc.

P.O. Box 1912

Las Vegas, NV 89125

L. Rogers, MS RLS-11

ICF Technology, Inc.

601 Williams Blvd.

Richland, WA 99352

G. W. Dawson

lowa State University

Ames, IA 50011

G. Junk

Lawrence Berkeley Laboratory

1 Cyclotron Road

Berkeley, CA 94720

T. McEvilly, 50E-111

6 Lawrence Livermore National Laboratory

P.O. Box 808

Livermore, CA 94550

M. Angel

R. Aines

K. Langry

B. McConachie

D. Rice

J. L. Yow
No. of

Copies

6 Los Alamos National Laboratory

Los Alamos, NM 87545

S. Booth

W. Hansen

J. Kruger

J. P. Shipley

E. Springer

R. Vocke

Martin Marietta Energy Systems

Hazardous Waste Remedial Actions Program

P.O. Box 2003

Oak Ridge, TN 37831-7606

R. Snipes

Martin Marietta Energy Systems

P.O. Box 2009

Oak Ridge, TN 37831-8097

J. Koger

2 Massachusetts Institute of

Technology

Plasma Fusion Center

167 Albany Street, NW 16-140

Cambridge, MA 02139

L. Bromberg

D. R. Cohn

3 Oak Ridge National Laboratory

P.O. Box 2008

Oak Ridge, TN 37831-6273

R. Jenkins

A. Malinauskas

R. Siegrist

Reynolds Electrical and Engineering Environmental and Health Division P.O. Box 98521

Las Vegas, NV 89193-8521

R. B. Evans 
No. of

Copies

Rice University

Department of Mathematical Sciences Houston, TX 77005

M. F. Wheeler

4 Sandia National Laboratories

P.O. Box 5800

Albuquerque, NM 87185

D. Berry

G. C. Frye

S. T. Purvis

J. Sprung

Savannah River National Laboratory

Environmental Sciences Division

Aiken, SC 29808

B. Looney, 773-42A

Stanford University

Department of Applied Earth Sciences

Stanford, CA 94305-2225

S. Gorelick

State of Washington Department of Ecology

Olympia, WA 98504

J. Breckel, M/S PV-11

U.S. Air Force

Tyndall AFB, FL 32403-6001

K. Vogel, HQ AFCESA/RAVW

U.S. Environmental Protection

Agency

944 East Harmon

Las Vegas, NV 89119

E. Koglin

U.S. Environmental Protection

Agency

712 Swift Blvd., Suite 5

Richland, WA 99352

D. R. Sherwood
No. of

Copies

U.S. Environmental Protection

Agency

Region 10

1200 Sixth Avenue

Seattle, WA 98101

J. Barich, ES-098

2 University of lowa

lowa City, IA 52242

R. L. Crawford

D. P. Eyman

University of Nevada

Remote Sensing Laboratory

P.O. Box 1912

Las Vegas, NV 87125

R. Jacobson, MS D-12

University of Washington

Seattle, WA 98105

H. D. Stensel

Washington State Nuclear Waste

Advisory Council

1063 South Capitol Way, Rm 212

Olympia, WA 98501

B. Tabbutt

Washington State University

100 Sprout Road

Richland, WA 99352

J. Conca

Westinghouse Idaho Nuclear

Company, Inc.

P.O. Box 4000

Idaho Falls, ID 83403-4000

T. R. Thomas

2 Westinghouse Materials Co. of Ohio

P.O. Box 398704

Cincinnati, OH $45239-8704$

J. P. Hopper

K. Nuhfer 
No. of

Conies

Roy F. Weston, Inc. 1907 Central, Suite 102

Los Alamos, NM 87544

B. Gilkeson

\section{ONSITE}

5 DOE Richland Operations Office

R. P. Carter

J. D. Goodenough

J. M. Hennig

P. M. Pak

D. E. Trader

2 Kaiser Engineers Hanford Company

H. A. Dugger

N. M. Hutchins

\section{Westinahouse Hanford Comoany}

M. R. Adams

J. D. Berger

M. P. Connelly

J. D. Fancher

K. R. Fecht

B. H. Ford

R. L. Gilchrist

M. C. Hagood

K. M. Hodgson

G. W. Jackson

R. L. Jackson

J. M. Jimenez

V. G. Johnson

W. L. Johnson

G. L. Kasza

C. V. King

A. J. Knepp

K. J. Koegler

O. L. Kruger

A. G. Law

R. E. Lerch

K. A. Lindsay

G. W. McLellan
No. of

Copies

D. J. Moak

S. M. Narbutovskih

M. G. Piepho

J. A. Rawlins

V. J. Rohay

M. J. Schliebe

J. L. Scott

K. J. Swett

S. J. Trent

B. W. Volk

J. G. Wollard

51 Pacific Northwest Laboratery

L. N. Archibald

M. P. Bergeron

T. M. Bergsman

B. N. Bjornstad

J. V. Borghese

T. M. Brouns

M. A. Chamness

D. E. Deonigi

P. G. Doctor

J. C. Evans

R. E. Engelman

M. J. Fayer

G. K. Gerke

W. O. Heath

E. C. Korstad (2)

G. V. Last

R. J. Lenhard

A. M. Lesperance

R. E. Lewis

S. P. Luttrell

G. H. McCabe, BSRC

F. A. Morris

T. L. Page

M. E. Peterson

R. G. Riley (5)

K. R. Roberson

M. L. Rockhold

R. Schalla

S. C. Slate

S. L. Stein

E. J. Stenehjem 
No. of

Copies

J. A. Stottlemyre

C. K. Thornhill

S. D. Tomich

M. J. Truex

C. L. Widrig

R. E. Wildung

G. L. Wilfert

S. B. Yabusaki

Publication Coordination

Technical Report Files (5)
No. of

Copies

Routing

R. M. Ecker

M. J. Graham

P. M. Irving

R. L. Skaggs

C. S. Sloane

P. C. Hays/B. V. Johnston (last) 

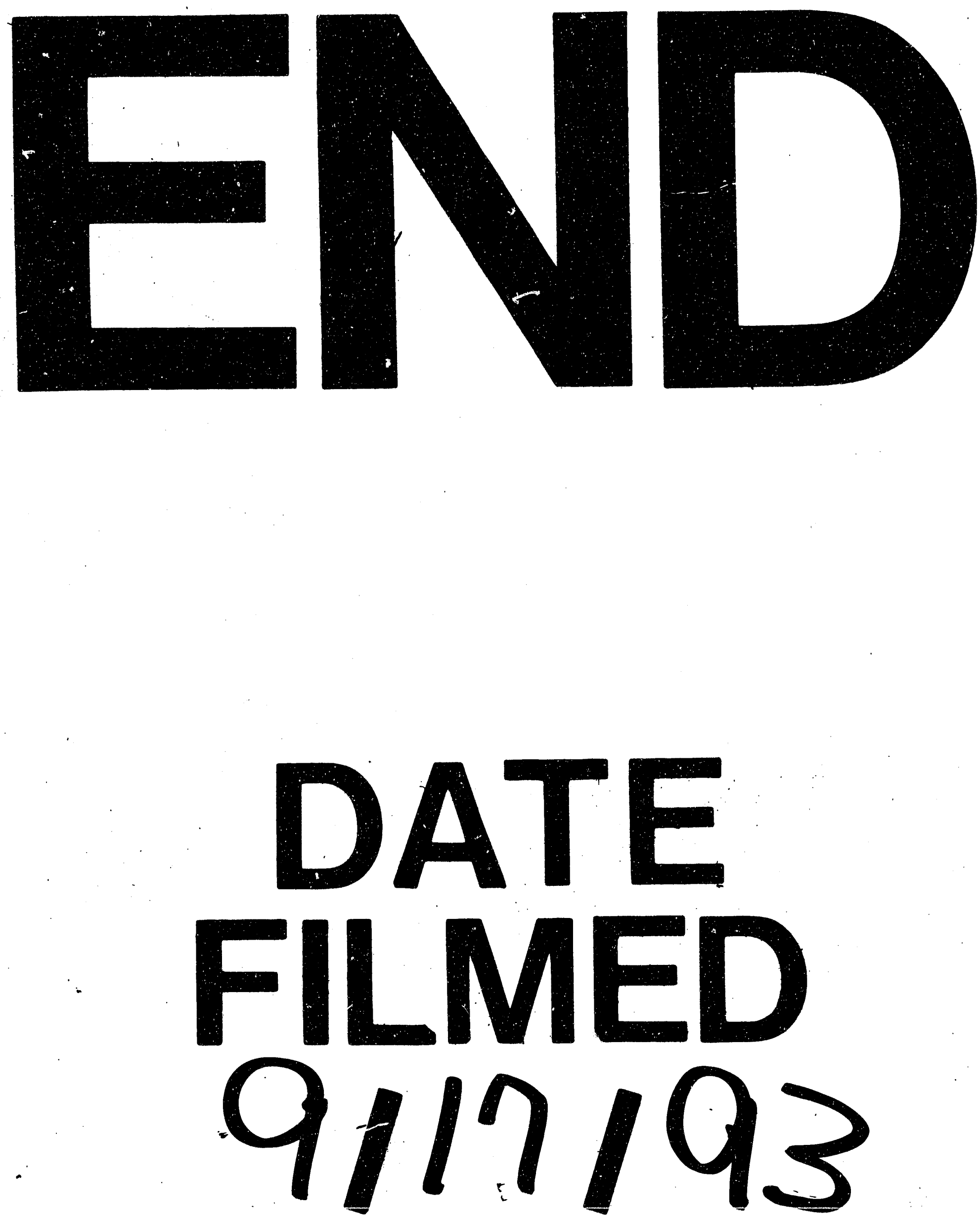
